ENTREPRENEURSHIP AND SUSTAINABILITY ISSUES

ISSN 2345-0282 (online) http://jssidoi.org/jesi/ 2020 Volume 8 Number 1 (September)

http://doi.org/10.9770/jesi.2020.8.1(10)

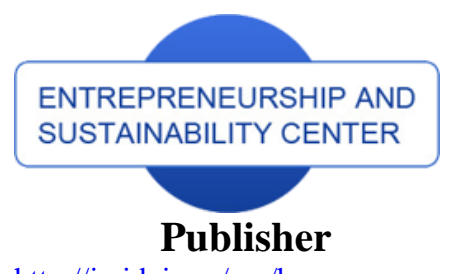

http://jssidoi.org/esc/home

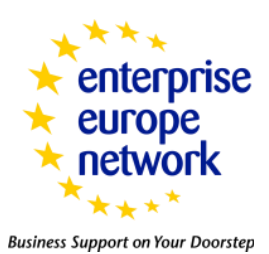

Business Support on Your Doorstep

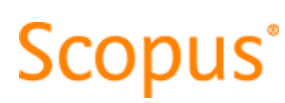

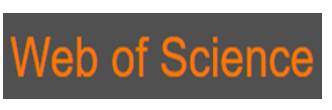

Clarivate
Analytics

\title{
MODELING CLUSTER DEVELOPMENT USING PROGRAMMING METHODS: CASE OF RUSSIAN ARCTIC REGIONS
}

\author{
Tatiana Kudryavtseva ${ }^{1}$, Angi Skhvediani ${ }^{2}$, Mohammed Ali Berawi ${ }^{3}$ \\ ${ }^{1,2}$ Peter the Great St. Petersburg Polytechnic University (SPbPU), Polytechnicheskaya, 29, St. Petersburg, 195251, Russia \\ ${ }^{3}$ University of Indonesia (UI), Kampus UI, Depok, 16424, Indonesia \\ E-mails:1kudryavtseva_tyu@spbstu.ru; ${ }^{2}$ shvediani_ae@spbstu.ru; ${ }^{3}$ maberawi@eng.ui.ac.id
}

Received 18 December 2019; accepted 15 June 2020; published 30 December 2020

\begin{abstract}
The aim of this research is to show how the process of data analysis can be automated through development of an information system. The information system can be used for the identification of economic clusters and analysis of the regional potential for economic growth. The authors used data on the Russian Arctic regions with extreme social, geographical, and economic conditions collected from 2009 to 2016 as an example. The authors have designed a database using MS Access software. The authors used the methodology of the European cluster observatory and the approach suggested by M. Porter to identify economic clusters. This methodology was complemented by introduction parameters, which mirror the strength and employment dynamic of the clusters. Based on the employment data of 83 Russian regions during the period of 2009-2016 the authors have calculated cluster localization parameters for nine Russian regions, which are partly or fully located in the Arctic zone. The authors suggest that the cluster structure in this area is weak and most of the significant clusters are declining. The only significant cluster, which is growing in all regions, is the «Oil and Gas» cluster. In conclusion, the authors state that the obtained results are vital for policy makers and can be used for elaborating the regional economic development strategy in order to support regional diversification and specialization, which are closely related to positive spillovers.
\end{abstract}

Keywords: Arctic region; economic cluster; cluster identification; MS access; data processing; regional policy making

Reference to this paper should be made as follows: Kudryavtseva, T., Skhvediani, A., Ali, M. 2020. Modeling cluster development using programming methods: case of Russian Arctic regions. Entrepreneurship and Sustainability Issues, 8(1), 150-176. http://doi.org/10.9770/jesi.2020.8.1(10)

JEL Classifications: $\mathrm{O} 1, \mathrm{O} 3$

\section{Introduction}

Creating conditions for the economic development of regions is one of the most important tasks for regional governments, who nowadays, in large part, are supported by informational systems (Morrissey, 2016; Rytova \& Gutman, 2019). During this process, a regional government should take into account social, economic, and

\footnotetext{
* The reported study was funded by the Russian Foundation for Basic Research (research project No. 18-31020012).
} 


\section{ENTREPRENEURSHIP AND SUSTAINABILITY ISSUES}

ISSN 2345-0282 (online) http://jssidoi.org/jesi/

2020 Volume 8 Number 1 (September)

http://doi.org/10.9770/jesi.2020.8.1(10)

geographical factors, which can affect the development of each concrete territory (Andreyeva et al., 2018; Dvas et al., 2018; Baltgailis, 2019; Petrenko et al., 2019).

A combination of these factors determines whether a certain region will or will not be capable of developing industries which will be competitive at national and international scales. Consequently, analysts should process multidimensional data which reflect the current situation. Based on such analyses, they should receive specific results, which can be used for determining potential directions for development of the region (Degtereva et al., 2018; Kichigin, 2017; Kozlov et al., 2017; Thill, 2019). Therefore, it is essential to develop informational systems to support and enhance the processes of policy making and, consequently, positively affect regional economic development (Chun et al., 2010; Höchtl et al., 2016; Velasquez \& Hester, 2013; Prodani et al., 2019).

A cluster approach to regional economic development put forth by Porter (1998) and developed further by a number of authors (Delgado et al., 2014, 2015; Tvaronavičienė, 2017; Tvaronavičienè \& Razminienė, 2017; Razminienė \& Tvaronavičienè, 2018; Bublienė et al., 2019), is one of the most innovative and effective tools for policy implementation. The results of applying a cluster approach in American (Gupta, et al., 2006; Guzman \& Stern, 2015; Peiró-Signes, et al., 2015; Porter et al., 2011), European (Crawley \& Pickernell, 2012; Looijen \& Heijman, 2013; Sellar, et al., 2011) and Russian (Islankina \& Thurner, 2018; Kutsenko et al., 2017; Rodionova et al., 2017) territories are widely represented in scientific literature. However, these applications are lacking in two main aspects which are essential for using this approach effectively in practice. The first aspect is that most of them are focused on receiving results, rather than making the process reproducible and applicable for other researches and practitioners. The second aspect is that they aim at finding global linkages between some factors and the level of cluster development (Akpinar et al., 2017; MATICIUC, 2015), but do not focus on concrete results for a concrete set of territories with extreme social, economic, and geographical conditions. This gap may lead to the development of a «cure» which is suitable for all territories, but in some extreme cases is ineffective and should be combined with some «additives». Therefore, it is necessary to describe how we can create an information system which will provide an analytical background for the development of the cluster-based policy and give examples of applying these results in territories with extreme social, economic, and geographical conditions.

As an example of such territories, we have chosen Russian regions which are partly or fully located in the Arctic zone (Leksin \& Porfiryev, 2017). These are poorly developed territories which have a certain economic potential (Borisov \& Pochukaeva, 2016; Komkov, et al., 2017; Korovkin, 2016). Developing these territories is claimed to be one of the top priorities for a balanced development of the Russian Federation (Gutman et al., 2018; Romashkina et al., 2017; Tatarkin et al., 2017). Developing an effective cluster-based policy, which relies on the results of comprehensive and multidimensional analysis, is key for long-term socioeconomic growth of the Russian Arctic regions (Komkov et al., 2017; Rytova et al., 2017).

Therefore, the aim of this research is to show how, through development of an information system, the process of data analysis can be automated, which is necessary for identifying and analyzing economic clusters. In addition, we demonstrate a potential approach to cluster structure analysis of the Russian Arctic regions, which have both extreme social, geographical, and economic conditions and a potential for economic growth, during 2009-2016.

\section{Data and methods}

\subsection{Data and cluster identification methodology}

In order to gather the information necessary for calculating the parameters of cluster localization, we obtained detailed data on employment from three main sources: the joint economic and social data archive of the Higher School of Economics (HSE, 2018), the Central Statistical Database of Russia (Federal State Statistics Service, 2019), and United Interdepartmental Information-Statistical Service (MinComSvyaz, 2019). These sources 


\section{ENTREPRENEURSHIP AND SUSTAINABILITY ISSUES}

ISSN 2345-0282 (online) http://jssidoi.org/jesi/ 2020 Volume 8 Number 1 (September)

http://doi.org/10.9770/jesi.2020.8.1(10)

provide official data obtained from the Russian Federal State Statistics Service. We used data from united interdepartmental information-statistical service as the main source of data, as it is better structured and contains more information. In some cases, when there were not enough data for some of the regions, we used data from the central statistical database of Russia and the joint economic and social data archive of the Higher School of Economics. The data were organized in the form presented in Table 1. As a result, we received 28044 observations for calculating the localization parameters of 37 clusters for 83 regions of Russia for the period of 2009-2016.

Table 1. Specifying the data used for identifying economic clusters in Russia

\begin{tabular}{|c|c|c|c|c|c|}
\hline Federal District & Region & Year & Cluster & $\begin{array}{c}\text { Number of the } \\
\text { employed }\end{array}$ \\
\hline $\begin{array}{c}\text { List of 8 Federal } \\
\begin{array}{c}\text { Districts, which } \\
\text { include Russian } \\
\text { regions }\end{array}\end{array}$ & $\begin{array}{c}\text { List of 83 Russian } \\
\text { regions }\end{array}$ & $\begin{array}{c}\text { Identifying the } \\
\text { time: } \\
2009-2016\end{array}$ & $\begin{array}{c}\text { List of 37 clusters, } \\
\text { identified according } \\
\text { to M. Porter's } \\
\text { classification for } \\
\text { each region }\end{array}$ & $\begin{array}{c}\text { Each of the 37 clusters is } \\
\text { composed of several } \\
\text { OKVED codes. } \\
\text { Therefore, for each } \\
\text { cluster, we detail its } \\
\text { composition }\end{array}$ & $\begin{array}{c}\text { For each code we } \\
\text { filled the number of } \\
\text { people employed in } \\
\text { the region }\end{array}$ \\
\hline $\begin{aligned} \text { Sources: Employment statistics by activity type were obtained from: (HSE, 2018), (Federal State Statistics Service, 2019), (MinComSvyaz, } \\
\text { 2019). Authors composed clusters based on employment statistics of separate types of activities, presented in each region. }\end{aligned}$ \\
\hline
\end{tabular}

We follow the methodology developed by Porter (1998), which is now used by the U.S. Mapping project and the European Cluster Observatory for identifying and monitoring cluster development. In particular, we use three coefficients which show the localization properties of each cluster: localization, focus, and size. This methodology was presented in detail by both developers (Ketels \& Protsiv, 2014), their followers (Kopczewska, 2018; Kopczewska et al., 2017) and the authors of this research study (Berawi, 2017; Berawi et. al., 2018; Schepinin et. al., 2018) in earlier works. The European Cluster Observatory defined these three factors as the «Localization coefficient» (1), «Size» (2), and «Focus» (3). The values of the factors, within the threshold values, reflects whether the examined cluster has or has not achieved a sufficient «critical mass» to generate positive external effects and relations. These indicators are calculated using employment statistics and are reflected in the following formulae:

$$
L Q=\frac{E_{i g}}{E_{q}} / \frac{E_{i}}{E}
$$

where LQ is the «Localization coefficient»; $E_{\text {iq }}$ is the number of people employed in cluster i in region $\mathrm{g} ; E_{q}$ is the total number of people employed in region $\mathrm{g} ; E_{\mathrm{i}}$ is the number of people employed in cluster $\mathrm{i}$; and $E$ is the total number of people employed.

$$
\text { Size }=\frac{E_{\text {ig }}}{E_{\mathrm{i}}}
$$

where Size is the «Size» of cluster i; $E_{\mathrm{i}, q}$ is the number of people employed in cluster i in region $\mathrm{g}$; and $E_{\mathrm{i}}$ is the number of people employed in cluster $i$.

$$
\text { Focus }=\frac{E_{\text {ig }}}{E_{q}},
$$

where Focus is the «Focus» of cluster $\mathrm{i} ; E_{i q q}$ is the number of people employed in cluster i in region $\mathrm{g}$; and $E_{q q}$ is the number of people employed in region $\mathrm{g}$.

G. Lindqvist, a Swedish economist from the European Cluster Observatory (Lindqvist, 2009), establishes the following criteria as the threshold values, which mark significant cluster groups in a region: 
1) «Localization coefficient» $\geq 2$;

http://doi.org/10.9770/jesi.2020.8.1(10)

2) the region should be included in top $10 \%$ in «Size»;

3) the region should be included in top $10 \%$ in «Focus».

In addition, a region cannot receive a star if critical mass of the cluster is less than 1000 employed people.

If a criterion is fulfilled, the cluster earns one «star». Thus, the maximum a cluster can receive is three «stars». The number of «stars» determines the strength of the cluster group

Table 2. Level of region specialization in types of activities performed by cluster $\mathrm{i}$ in region $\mathrm{g}$

\begin{tabular}{|c|c|}
\hline Level of region specialization & Average number of stars, obtained by cluster i in region g \\
\hline High & $(2.3 ; 3]$ \\
\hline Medium & $(1.7 ; 2.4]$ \\
\hline Low & {$[1 ; 1.7]$} \\
\hline Region has no specialization in this type of activity & {$[0 ; 1)$} \\
\hline
\end{tabular}

In order to systemize the results and present them more clearly, we also separate regions by two dimensions: the level of specialization in types of activities, performed by cluster $i$ (Table 2) in region $g$ and the dynamic state of employment of cluster $i$ in region $g$ (Table 3). We have built dimension «levels of region specialization» in types of activities performed by cluster $i$ in region $g$ based on the average number of stars which cluster $i$ in region $g$ receives for the analyzed period, while the second dimension is based on the employment dynamics, calculated through the growth rate:

$$
\begin{gathered}
G R_{t=0}=\left(\frac{x_{\text {igt }}}{x_{\text {iqt }}=0}-1\right) \times 100 \%, \\
G R_{t}=\left(\frac{x_{\text {igt }+1}}{x_{\text {iqt }}}-1\right) \times 100 \%,
\end{gathered}
$$

The growth rate allows estimating the change in clusters' critical mass and reflecting the dynamic aspect of cluster growth, where $x_{i q t=0}$ is the number of people employed in cluster $i$ in region $g$ at the beginning $(t=0)$ of the analyzed period, and $x_{\text {iqt }}$ is the number of people employed in cluster $i$ in region $g$ at the time $t \geq 1$ and $x_{i q a t+1}$ - at the time $t+1 . G R_{t=0}$ is the measure for calculating long-term employment dynamics, while $G R_{t}$ is used for the short-term. In Table 3 we propose a possible classification of dynamic states of the cluster depending on the values of $G R_{0}$ and $G R_{t}$ at the end of the period and their overall dynamics. It complements the existing localization measures, since the main problem of the «Size», «Focus», and «Localization coefficient» is their independence from the time trend. It means that if employment of the cluster, employment of the whole cluster group, and total employment are decreasing, the «Localization coefficient» remains stable, and vice versa, since it cannot catch up with dynamic changes in employment in certain cases

\begin{tabular}{|c|c|c|}
\hline Dynamic state & Characteristic & $\begin{array}{l}\text { Interval for } G R_{t=0} \text { and } G R_{t} \text {, } \\
\%\end{array}$ \\
\hline Strong growth & Strong positive employment dynamics & {$\left[10_{m}+\infty\right)$} \\
\hline Moderate growth & Moderate positive employment dynamics & {$[5 ; 10)$} \\
\hline Stable & Stable employment dynamics with slight changes in employment & $(-5 ;+5)$ \\
\hline Unstable & $\begin{array}{l}\text { Employment dynamics with rough positive and/or negative changes } \\
\text { at the beginning, in the middle or at the end of the period }\end{array}$ & $\begin{array}{l}{[5 x+\infty)} \\
\text { and/or } \\
(-\infty,-5]\end{array}$ \\
\hline Moderate decrease & Moderate negative employment dynamics & $\left(-10_{i}-5\right]$ \\
\hline Strong decrease & Strong negative employment dynamics & $(-\infty-10]$ \\
\hline
\end{tabular}

Table 3. Types of dynamic state of employment of cluster $i$ in region $g$

Source: Compiled by aurhors 


\section{ENTREPRENEURSHIP AND SUSTAINABILITY ISSUES}

ISSN 2345-0282 (online) http://jssidoi.org/jesi/

2020 Volume 8 Number 1 (September)

\subsection{Description of information system used for automated cluster identification}

http://doi.org/10.9770/jesi.2020.8.1(10)

The database «Clusters of Russia's Regions» was developed and registered in 2017 in order to support research of the cluster structure in Russia. During the development process, we wanted to achieve the following objectives:

- structuring and rationalizing big data concerning employment in different clusters in the Russian regions;

- creating a convenient system for data input and editing;

- creating a computing mechanism for estimating the localization coefficients for clusters in a certain year;

- creating a flexible system which can be modified in case some regions have to be added or new clusters have to be defined;

- $\quad$ automating the estimation results and converting them into analytical reports.

A user receives the results of analysis in the form of summary tables, where main results are given for each region and each cluster. The results are calculated in accordance with the methodology discussed in Paragraph 2.1.

Based on the research of the data structure we created four entities: «Federal District», «Region», «Cluster», and «Employment». These entities allow us to minimize input errors and provide integrity of data. The entity «Federal District» has two attributes: an identifier (which is a primary key), and a label. This table is a glossary, which provides secure and convenient input of data in interconnected objects and access to the groups of regions. The entity «Region» belongs only to one Federal District and cannot exist independently. Therefore, apart from its own primary key, it has a secondary key for connection with the entity «Federal District». The entity «Cluster» has two main attributes: a short label and a named key. Additional attributes are used for interface organization, because long labels take too much space and are not suitable for usage in headlines and summary tables. The entity «Employment» contains two external keys for connection with «Region» and «Cluster» and a nested primary key, which protects the table from data duplication since only one cluster i can be created for each region in a certain time period. Therefore, each cluster can be uniquely determined through such attributes as year, region, and cluster. For the sake of convenient data processing, we have also added a counter, which defines the unique nested key. The database evaluates the following attributes: «Localization coefficient», «Size», «Focus», and «Number of stars» (Table 4).

Table 4. Attributes of entity «Employment»

\begin{tabular}{|c|c|}
\hline Attribute title & Attribute label \\
\hline Year & YearEpml \\
\hline Region & IdRegion \\
\hline Cluster & IdIndustry \\
\hline Empig & Empig \\
\hline Size & Esize \\
\hline Focus & EFocus \\
\hline LQ & ELQ \\
\hline Stars & Estars \\
\hline Source: Compiled by aurhors
\end{tabular}

In order to organize the data input and provide immediate access to the clusters, a temporary entity, «Computation», with a varying number of attributes, has been introduced. It adapts for each region and cluster in a specific time period.

The physical model is SQL-based and realized in DBMS MS Access 2007 (Figure 1). 


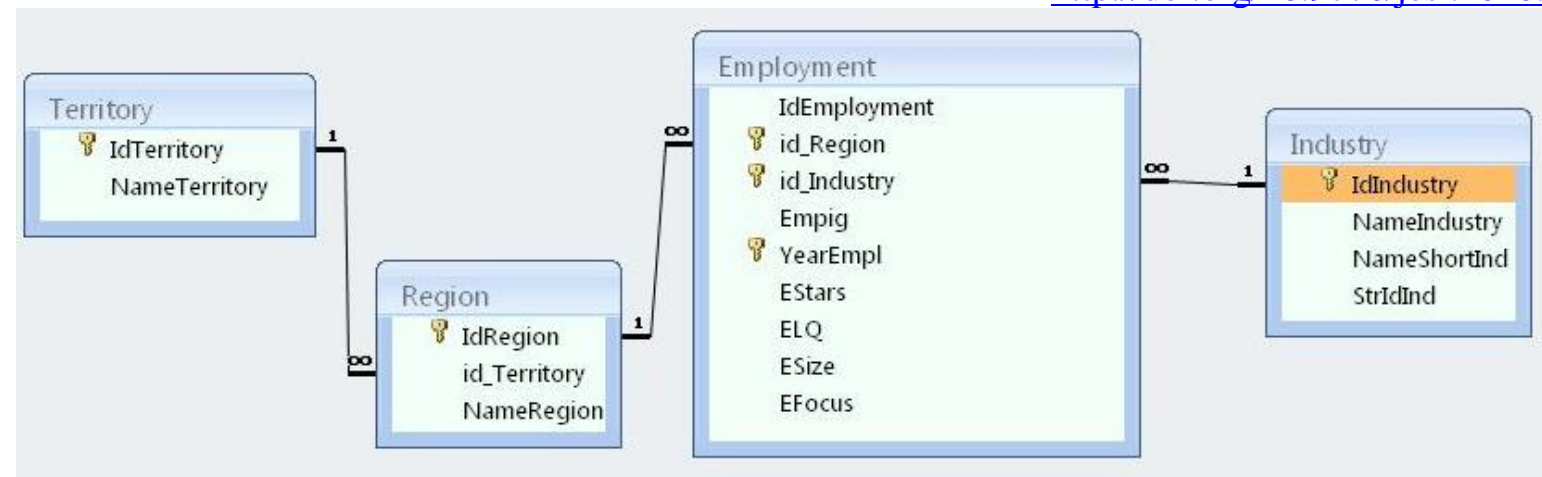

Source: Compiled by Authors

Figure 1. Physical model of «Clusters of Russia’s Regions».

The table «Employment» contains data, which is used for calculation and data processing. Other tables provide a safe and convenient form for data input and make the main table free from redundant data. Using equations 1-3 the program calculates total employment by each region, each cluster, and each year. In order to implement calculations, we developed a chain of query operators and the function CalcStars (Figure 2). The program calculates the results and inputs them into the main table. The data from this table has to be analyzed and selected for display. A chain of query operators for displaying the result is presented in Figure 3.

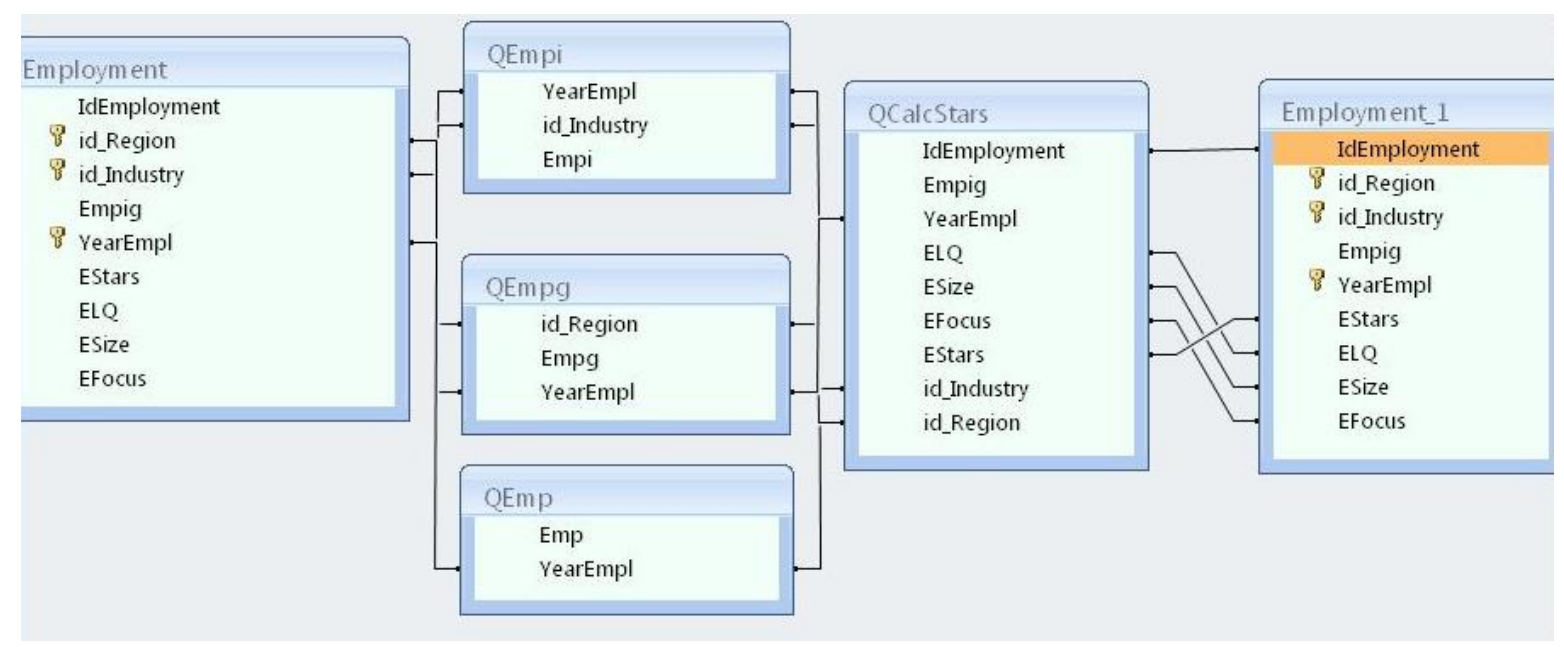

Source: Compiled by Authors

Figure 2. A calculation model of the database 


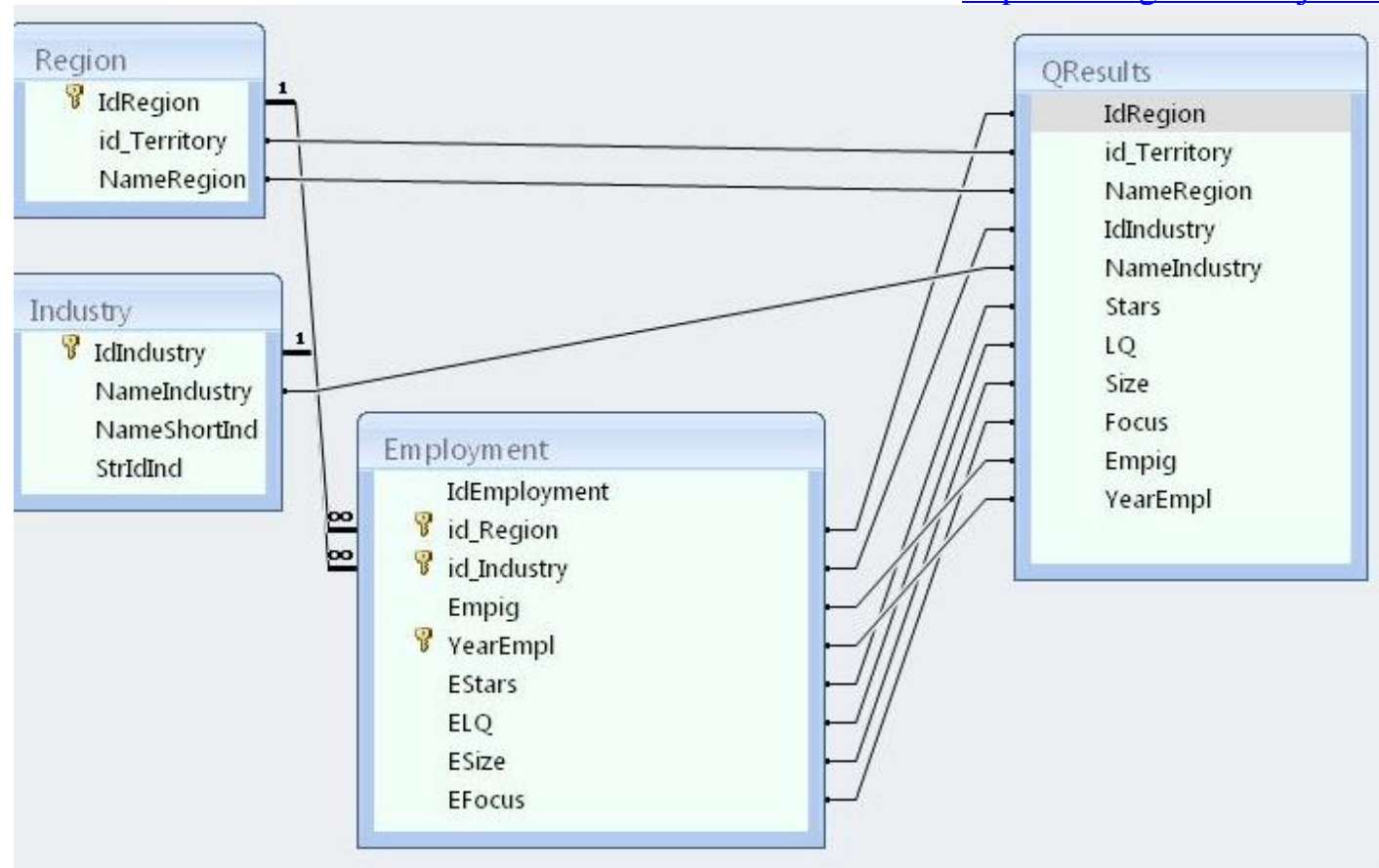

Source: Compiled by Authors

Figure 3. A chain of query operators for displaying the result

\section{Results of database application}

\subsection{General information}

In accordance with the methodology for cluster identification discussed in Section 2.1 and the database design presented in section 2.2, we have received analytical results for all 83 Russian regions for the 2009-2016 period.

Here we discuss only the results obtained for the Russian regions, which are partly or fully located in the Arctic zone. These regions are the following:

- Murmansk Oblast;

- Chukotka Autonomous Okrug;

- Komi Republic;

- Arkhangelsk Oblast including Nenets Autonomous Okrug;

- Yamalo-Nenets Autonomous Okrug;

- Sakha Republic;

- Republic of Karelia;

- Krasnoyarsk Krai;

- Khanty-Mansi Autonomous Okrug. 


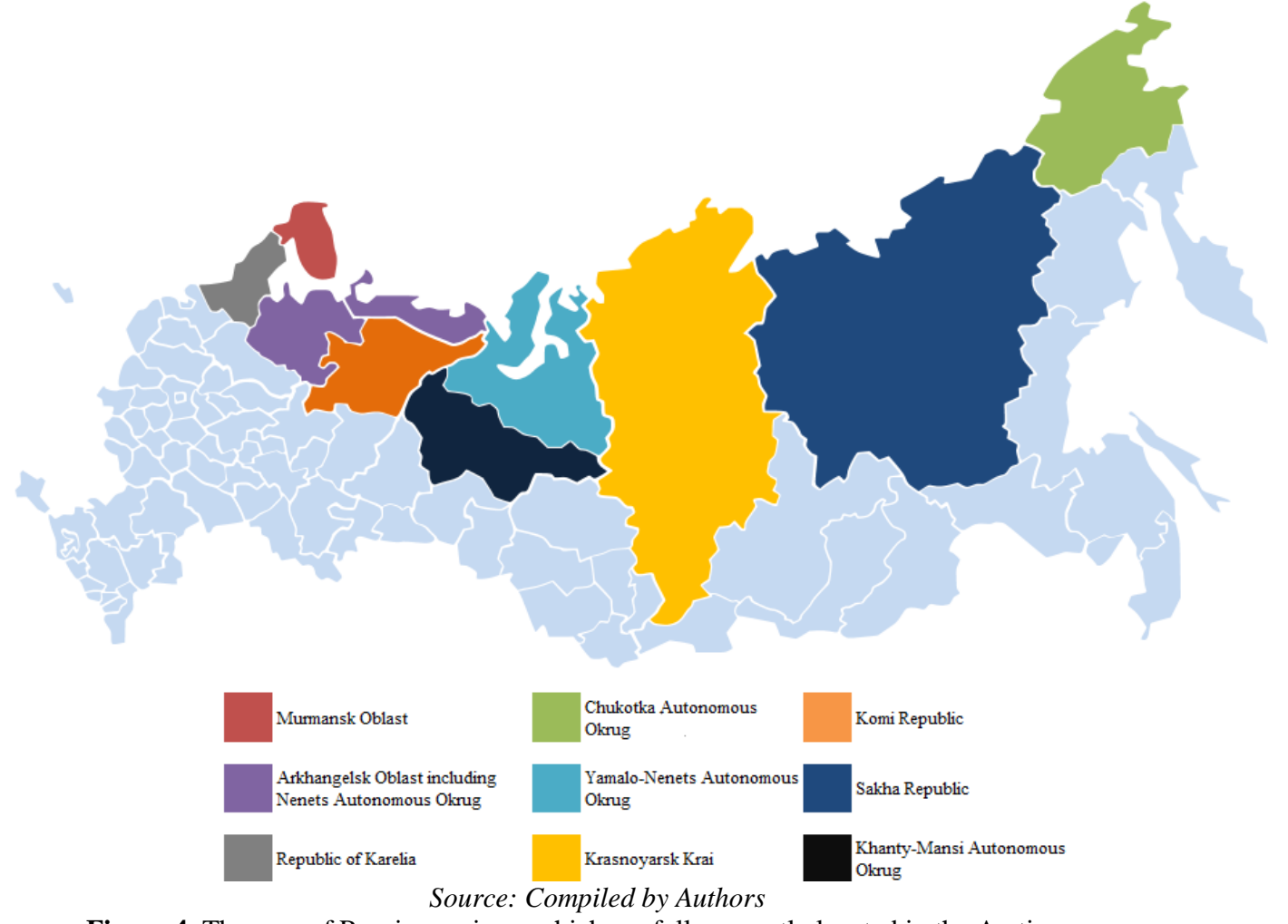

Figure 4. The map of Russian regions, which are fully or partly located in the Arctic zone

The geographical location of the regions we analyze is presented in Figure 4. Next, we present a detailed analysis of cluster specialization of each Arctic region of Russia and, after that, aggregate the results for all arctic regions.

\section{Komi Republic cluster specialization analysis}

The overall employment dynamic in Komi Republic was negative. The total number of employed people decreased by $13.97 \%$ or by 53,967 people over eight years. Analyzing the employment statistics in Komi Republic during the period of 2009-2016, we have detected five clusters: Transportation and Logistics, Oil and Gas, Paper Products, Business Services, and Construction, with all of them receiving at least one star. It means that the level of localization of these clusters, at least in one year, was relatively high in accordance with the values of the «Localization Coefficient», «Size», and «Focus». The detailed results are presented in Table 5.

Komi Republic had a medium specialization level in Transportation and Logistics and the critical mass of this cluster was unstable during the analyzed period. After a decrease of the clusters' employment by $1.07 \%$ in 2010 , there was a significant growth of the clusters' critical mass from 36,403 up to the 43,756 people; that is, by $19.7 \%$ in 2012. After that, there was a stable decrease in the Transportation and Logistics cluster's critical mass: $19.35 \%$ in 2016 compared to 2012. Nevertheless, the overall specialization of the region in Transportation and Logistics activities remained at a medium level, since two localization measures out of three fulfilled the threshold requirements.

Komi Republic had a high specialization level in Oil and Gas and the critical mass of this cluster grew significantly during the analyzed period, despite some falls in 2011 and 2016. The overall increase of the cluster's critical mass was $25.76 \%$ over eight years. This resulted in a stronger specialization of the cluster and its stabilization at the high level, since three out of three localization measures fulfilled the threshold requirements. 


\section{ENTREPRENEURSHIP AND SUSTAINABILITY ISSUES}

ISSN 2345-0282 (online) http://jssidoi.org/jesi/ 2020 Volume 8 Number 1 (September) http://doi.org/10.9770/jesi.2020.8.1(10)

Komi Republic had a high specialization level in Paper Products and the critical mass of its cluster substantially decreased during the period of 2009-2016. The overall decrease of the clusters' critical mass was $27.61 \%$ over eight years. In addition, the decrease in the critical mass of the Paper Products cluster in Komi Republic was significantly greater than the overall decrease in the critical mass of the Paper Products Cluster, being 27.61\% compared to $4.78 \%$. It resulted in Komi Republic losing one star of cluster specialization in 2016, since one of the three localization measures did not fulfill the threshold requirements.

Komi Republic lost specialization in Business Services in 2012, since the cluster's critical mass decreased by $23.02 \%$ over eight years, while the cluster's overall critical mass increased by $7.41 \%$. The breakpoint was in 2011-2012, when two localization measures did not fulfill the threshold requirements.

Specialization of Komi Republic in Construction was detected in the period of 2012-2013, when a sudden increase in employment levels brought about a fall in the construction cluster localization. However, it was a short-term increase, which did not allow the regional specialization to strengthen in the long run. Therefore, the long-term decrease of the cluster's critical mass in Komi Republic was $21.80 \%$.

Table 5. Employment-based parameters of significant clusters in Yamalo-Nenets AO

\begin{tabular}{|c|c|c|c|c|c|c|c|c|}
\hline Parameter $\quad$ Year & 2009 & 2010 & 2011 & 2012 & 2013 & 2014 & 2015 & 2016 \\
\hline \multicolumn{9}{|c|}{ Common employment parameters } \\
\hline$E$ (people) & 47427502 & 46719007 & 45872388 & 45898382 & 45815640 & 45486400 & 45106533 & 44446352 \\
\hline$E_{g}$ (people) & 386402 & 382869 & 383163 & 382155 & 373393 & 360442 & 347562 & 332435 \\
\hline \multicolumn{9}{|c|}{ Transportation and Logistics cluster parameters } \\
\hline$E_{i}$ (people) & 3489740 & 3370683 & 3371228 & 3400956 & 3360962 & 3377649 & 3352174 & 3308218 \\
\hline$E_{i, g}$ (people) & 36797 & 36403 & 41187 & 43756 & 41241 & 39560 & 37282 & 35289 \\
\hline$G R_{i}(96)$ & & -1.07 & 13.14 & 6.24 & -5.75 & -4.08 & -5.76 & -5.35 \\
\hline$\left.G R_{t=0}(96)\right]$ & & -1.07 & 11.93 & 18.91 & 12.08 & 7.51 & 1.32 & -4.10 \\
\hline Number of stars & 1 & 1 & 2 & 2 & 2 & 2 & 2 & 2 \\
\hline LQ & 1.29 & 1.32 & 1.46 & 1.55 & 1.51 & 1.48 & 1.44 & 1.43 \\
\hline Size $(96]$ & 1.05 & 1.08 & 1.22 & 1.29 & 1.23 & 1.17 & 1.11 & 1.07 \\
\hline Focus $(96)$ & 9.52 & 9.51 & 10.75 & 11.45 & 11.04 & 10.98 & 10.73 & 10.62 \\
\hline \multicolumn{9}{|c|}{ Oil and Gas cluster parameters } \\
\hline$E_{i}$ (people) & 504955 & 504478 & 517301 & 536739 & 556754 & 578881 & 594546 & 606641 \\
\hline$E_{i, g}$ (people) & 14858 & 15782 & 15357 & 15699 & 16624 & 18676 & 19911 & 18685 \\
\hline$G R_{t}(96)$ & & 6.22 & -2.69 & 2.23 & 5.89 & 12.34 & 6.61 & -6.16 \\
\hline$G R_{t=0}(96)$ & & 6.22 & 3.36 & 5.66 & 11.89 & 25.70 & 34.01 & 25.76 \\
\hline Number of stars & 3 & 3 & 3 & 3 & 3 & 3 & 3 & 3 \\
\hline LQ & 3.61 & 3.82 & 3.55 & 3.51 & 3.66 & 4.07 & 4.35 & 4.12 \\
\hline Size $(\%)$ & 2.94 & 3.13 & 2.97 & 2.92 & 2.99 & 3.23 & 3.35 & 3.08 \\
\hline Focus $(\%)$ & 3.85 & 4.12 & 4.01 & 4.11 & 4.45 & 5.18 & 5.73 & 5.62 \\
\hline \multicolumn{9}{|c|}{ Paper Products cluster parameters } \\
\hline$E_{i}$ (people) & 137015 & 136152 & 137499 & 136273 & 132216 & 128119 & 125839 & 130471 \\
\hline$E_{i g}$ (people) & 4810 & 4709 & 4444 & 4195 & 4181 & 3769 & 3611 & 3482 \\
\hline$G R_{t}(96)$ & & -2.10 & -5.63 & -5.60 & -0.33 & -9.85 & -4.19 & -3.57 \\
\hline$G R_{t=0}(96)$ & & -2.10 & -7.61 & -12.79 & -13.08 & -21.64 & -24.93 & -27.61 \\
\hline Number of stars & 3 & 3 & 2 & 3 & 3 & 3 & 3 & 2 \\
\hline LQ & 4.31 & 4.22 & 3.87 & 3.70 & 3.88 & 3.71 & 3.72 & 3.57 \\
\hline Size (\%)] & 3.51 & 3.46 & 3.23 & 3.08 & 3.16 & 2.94 & 2.87 & 2.67 \\
\hline Focus $(\%)$ & 1.24 & 1.23 & 1.16 & 1.10 & 1.12 & 1.05 & 1.04 & 1.05 \\
\hline \multicolumn{9}{|c|}{ Business services cluster parameters } \\
\hline$E_{i}$ (people) & 2969478 & 2921201 & 2880799 & 3146204 & 3237312 & 3272631 & 3257275 & 3189467 \\
\hline$E_{i g}($ people $)$ & 32156 & 32050 & 31026 & 29169 & 27946 & 26602 & 26282 & 24755 \\
\hline$G R_{t}(\%)$ & & -0.33 & -3.20 & -5.99 & -4.19 & -4.81 & -1.20 & -5.81 \\
\hline$G R_{t=0}(\%)$ & & -0.33 & -3.51 & -9.29 & -13.09 & -17.27 & -18.27 & -23.02 \\
\hline
\end{tabular}




\section{ENTREPRENEURSHIP AND SUSTAINABILITY ISSUES}

ISSN 2345-0282 (online) http://jssidoi.org/jesi/ 2020 Volume 8 Number 1 (September)

http://doi.org/10.9770/jesi.2020.8.1(10)

\begin{tabular}{|c|c|c|c|c|c|c|c|c|}
\hline Number of stars & 2 & 2 & 1 & 0 & 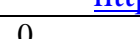 & 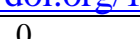 & 0 & $\frac{20}{10}$ \\
\hline LQ & 1.33 & 1.34 & 1.29 & 1.11 & 1.06 & 1.03 & 1.05 & 1.04 \\
\hline Size (96] & 1.08 & 1.10 & 1.08 & 0.93 & 0.86 & 0.81 & 0.81 & 0.78 \\
\hline Focus $(\%)$ & 8.32 & 8.37 & 8.10 & 7.63 & 7.48 & 7.38 & 7.56 & 7.45 \\
\hline \multicolumn{9}{|c|}{ Construction cluster parameters } \\
\hline$E_{i}$ (people) & 3425797 & 3430749 & 3163493 & 3254308 & 3225983 & 3123938 & 2983398 & 2800194 \\
\hline$E_{i g}($ people $)$ & 28568 & 28673 & 29713 & 35404 & 34969 & 29572 & 24566 & 22340 \\
\hline$G R_{t}(96)$ & & 0.37 & 3.63 & 19.15 & -1.23 & -15.43 & -16.93 & -9.06 \\
\hline$G R_{t=0}(96)$ & & 0.37 & 4.01 & 23.93 & 22.41 & 3.51 & -14.01 & -21.80 \\
\hline Number of stars & 0 & 0 & 0 & 1 & 2 & 0 & 0 & 0 \\
\hline LQ & 1.02 & 1.02 & 1.12 & 1.31 & 1.33 & 1.19 & 1.07 & 1.07 \\
\hline Size (96] & 0.83 & 0.84 & 0.94 & 1.09 & 1.08 & 0.95 & 0.82 & 0.80 \\
\hline Focus $(96]$ & 7.39 & 7.49 & 7.75 & 9.26 & \begin{tabular}{|l|}
9.37 \\
\end{tabular} & 8.20 & 7.07 & 6.72 \\
\hline
\end{tabular}

Out of the five clusters identified in Komi Republic during 2009-2016, only two clusters had a relatively high critical mass, which was enough for the region to have specialization in these types of activities. One cluster was decreasing-Paper Products - and one was growing-Oil and Gas. In addition, the region had medium specialization in Transportation and Logistics, which had unstable growth rates. The Business Services cluster was decreasing steadily, which resulted in Komi Republic losing specialization in this type of activity, and the Construction Cluster showed unstable employment dynamics.

Yamalo-Nenets AO cluster specialization analysis

The overall employment dynamic in Yamalo-Nenets AO was positive. The total number of people employed increased by $5.65 \%$, or by 18,018 people over eight years. Analyzing Yamalo-Nenets AO employment statistics during the period of 2009-2016, we detected five clusters: Transportation and Logistics, Maritime, Oil and Gas, Business Services, and Construction, which have received at least one star. Detailed results are presented in Table 6

Table 6. Employment-based parameters of significant clusters in Yamalo-Nenets AO

\begin{tabular}{|c|c|c|c|c|c|c|c|c|}
\hline Parameter $\quad$ Year & 2009 & 2010 & 2011 & 2012 & 2013 & 2014 & 2015 & 2016 \\
\hline \multicolumn{9}{|c|}{ Common employment parameters } \\
\hline$E$ (people) & 47427502 & 46719007 & 45872388 & 45898382 & 45815640 & 45486400 & 45106533 & 44446352 \\
\hline$E_{q}($ people $)$ & 319089 & 314503 & 311693 & 328308 & 333527 & 329129 & 331108 & 337107 \\
\hline \multicolumn{9}{|c|}{ Transportation and Logistics cluster parameters } \\
\hline$E_{\tilde{f}}$ (people) & 39386 & 35633 & 36513 & 40414 & 41824 & 37802 & 34637 & 34997 \\
\hline$E_{\text {iq }}($ people $)$ & & -9.53 & 2.47 & 10.68 & 3.49 & -9.62 & -8.37 & 1.04 \\
\hline$G R_{t}(\%)$ & & -9.53 & -7.29 & 2.61 & 6.19 & -4.02 & -12.06 & -11.14 \\
\hline$G R_{t=0}(\%)$ & 2 & 2 & 2 & 2 & 2 & 2 & 2 & 2 \\
\hline Number of stars & 1.68 & 1.57 & 1.59 & 1.66 & 1.71 & 1.55 & 1.41 & 1.39 \\
\hline LQ & 1.13 & 1.06 & 1.08 & 1.19 & 1.24 & 1.12 & 1.03 & 1.06 \\
\hline Size (\%) & 12.34 & 11.33 & 11.71 & 12.31 & 12.54 & 11.49 & 10.46 & 10.38 \\
\hline Focus $(\%)$ & 39386 & 35633 & 36513 & 40414 & 41824 & 37802 & 34637 & 34997 \\
\hline \multicolumn{9}{|c|}{ Maritime cluster parameters } \\
\hline$E_{\tilde{i}}$ (people) & 148225 & 152423 & 136905 & 129441.6 & 126963 & 116436.8 & 116557 & 114799 \\
\hline$E_{i q}$ (people) & 2468 & 2267 & 2212 & 2153 & 2151 & 2102 & 2110 & 2093 \\
\hline$G R_{t}(\%)$ & & -8.14 & -2.43 & -2.67 & -0.09 & -2.28 & 0.38 & -0.81 \\
\hline$G R_{t=0}(\%)$ & & -8.14 & -10.37 & -12.76 & -12.84 & -14.83 & -14.51 & -15.19 \\
\hline Number of stars & 1 & 1 & 1 & 1 & 1 & 1 & 1 & 1 \\
\hline LQ & 2.47 & 2.21 & 2.38 & 2.33 & 2.33 & 2.49 & 2.47 & 2.40 \\
\hline Size $(\%)$ & 1.67 & 1.49 & 1.62 & 1.66 & 1.69 & 1.81 & 1.81 & 1.82 \\
\hline Focus $(\%)$ & 0.77 & 0.72 & 0.71 & 0.66 & 0.64 & 0.64 & 0.64 & 0.62 \\
\hline
\end{tabular}


ENTREPRENEURSHIP AND SUSTAINABILITY ISSUES

ISSN 2345-0282 (online) http://jssidoi.org/jesi/ 2020 Volume 8 Number 1 (September) http://doi.org/10.9770/jesi.2020.8.1(10)

\begin{tabular}{|c|c|c|c|c|c|c|c|c|}
\hline \multicolumn{9}{|c|}{ Oil and Gas cluster parameters } \\
\hline$E_{\bar{i}}$ (people) & 504955 & 504478 & 517301 & 536739 & 556754 & 578881 & 594546 & 606641 \\
\hline$G R_{t}(\%)$ & & -0.39 & 6.60 & 3.87 & 6.70 & 3.76 & 4.26 & 2.02 \\
\hline$G \boldsymbol{R}_{t=0}(\%)$ & & -0.39 & 6.19 & 10.30 & 17.69 & 22.12 & 27.32 & 29.89 \\
\hline Number of stars & 3 & 3 & 3 & 3 & 3 & 3 & 3 & 3 \\
\hline $\mathbf{L Q}$ & 9.41 & 9.38 & 9.66 & 9.18 & 9.28 & 9.32 & 9.32 & 9.02 \\
\hline Size $(\%)$ & 6.33 & 6.31 & 6.56 & 6.57 & 6.76 & 6.74 & 6.84 & 6.84 \\
\hline Focus $(\%)$ & 10.02 & 10.12 & 10.89 & 10.74 & 11.28 & 11.86 & 12.29 & 12.31 \\
\hline \multicolumn{9}{|c|}{ Business Services cluster parameters } \\
\hline$E_{\tilde{i}}$ (people) & 2969478 & 2921201 & 2880799 & 3146204 & 3237312 & 3272631 & 3257275 & 3189467 \\
\hline$E_{\text {iq }}$ (people) & 20241 & 23056 & 24426 & 27574 & 28247 & 28332 & 29160 & 31328 \\
\hline$G R_{t}(\%)$ & & 13.91 & 5.94 & 12.89 & 2.44 & 0.30 & 2.92 & 7.43 \\
\hline$G R_{t=0}(\%)$ & & 13.91 & 20.68 & 36.23 & 39.55 & 39.97 & 44.06 & 54.77 \\
\hline Number of stars & 0 & 0 & 1 & 1 & 1 & 1 & 1 & 1 \\
\hline $\mathbf{L Q}$ & 1.01 & 1.17 & 1.25 & 1.23 & 1.20 & 1.20 & 1.22 & 1.30 \\
\hline Size $(\%)$ & 0.68 & 0.79 & 0.85 & 0.88 & 0.87 & 0.87 & 0.90 & 0.98 \\
\hline Focus $(\%)$ & 6.34 & 7.33 & 7.84 & 8.40 & 8.47 & 8.61 & 8.81 & 9.29 \\
\hline \multicolumn{9}{|c|}{ Construction cluster parameters } \\
\hline$E_{\hat{i}}$ (people) & 3425797 & 3430749 & 3163493 & 3254308 & 3225983 & 3123938 & 2983398 & 2800194 \\
\hline$E_{\text {iq }}$ (people) & 49716 & 48086 & 44634 & 51707 & 52911 & 52487 & 53417 & 55937 \\
\hline$G R_{t}(\%)$ & & -3.28 & -7.18 & 15.85 & 2.33 & -0.80 & 1.77 & 4.72 \\
\hline$G R_{t=0}(\%)$ & & -3.28 & -10.22 & 4.00 & 6.43 & 5.57 & 7.44 & 12.51 \\
\hline Number of stars & 2 & 2 & 2 & 2 & 2 & 2 & 2 & 2 \\
\hline LQ & 2.16 & 2.08 & 2.08 & 2.22 & 2.25 & 2.32 & 2.44 & 2.63 \\
\hline Size $(\%)$ & 1.45 & 1.40 & 1.41 & 1.59 & 1.64 & 1.68 & 1.79 & 2.00 \\
\hline Focus $(\%)$ & 15.58 & 15.29 & 14.32 & 15.75 & 15.86 & 15.95 & 16.13 & 16.59 \\
\hline
\end{tabular}

Yamalo-Nenets AO had a medium specialization level in Transportation and Logistics and the critical mass of this cluster was unstable during the analyzed period. After a 9.53\% decrease of the cluster's employment in 2010 , there was a significant growth of the cluster's critical mass, from 35,633 up to 41,824 people employed; that is, by $17.3 \%$ in 2013 compared to 2010. After that, there was a stable decrease of the Transportation and Logistics cluster's critical mass: $16.32 \%$ in 2016 compared to 2013. Nevertheless, the overall specialization of the region in Transportation and Logistics activities remained at a medium level, since two localization measures out of three fulfilled the threshold requirements.

Yamalo-Nenets AO had a low specialization in Maritime. However, the critical mass of this cluster decreased by $15.19 \%$ during the analyzed period. The region still has a certain margin of safety in relative terms, since the overall employment in Maritime activities decreased by $22.55 \%$ over eight years. However, in terms of absolute values, the region was continuously losing its specialization in this type of activity.

Yamalo-Nenets AO had a high specialization level in Oil and Gas, and the critical mass of this cluster was growing significantly during the analyzed period. The overall increase of the cluster's critical mass was $29.89 \%$ over eight years. This resulted in a stronger specialization of the cluster and its stabilization at a high level, since three localization measures out of three fulfilled the threshold requirements.

Yamalo-Nenets AO was strengthening its specialization in Business Services, since the cluster's critical mass in Yamalo-Nenets AO increased by $54.07 \%$ over eight years, while the cluster's overall critical mass increased by $7.41 \%$. The breakpoint was in 2011 , when one localization measure fulfilled the threshold requirements. 


\section{ENTREPRENEURSHIP AND SUSTAINABILITY ISSUES}

ISSN 2345-0282 (online) http://jssidoi.org/jesi/ 2020 Volume 8 Number 1 (September) http://doi.org/10.9770/jesi.2020.8.1(10) Yamalo-Nenets AO had a medium specialization level in Construction and the critical mass of this cluster was unstable during the analyzed period. There was a 3.28\% decrease in the cluster's employment in 2010, and a 7.18\% decrease in 2011. After that, there was a significant growth of the cluster's critical mass, from 44,634 in 2011 up to 55,937 people; that is, by $25.32 \%$ in 2016. It resulted in a stronger specialization of the cluster and its stabilization at a high level, since two localization measures out of three fulfilled the threshold requirements.

Yamalo-Nenets AO was strongly specialized in only one cluster, showing a steady growth of the critical massthe Oil and Gas cluster. In addition, the region had a medium specialization in the Transportation and Logistics and Construction clusters, which had unstable growth rates. The Maritime cluster was decreasing considerably, which resulted in Yamalo-Nenets AO losing specialization in this type of activity. The Business Services cluster demonstrated an intensive growth, which resulted in a stronger specialization of the cluster, since one localization measure out of three fulfilled the threshold requirements.

\section{Republic of Karelia cluster specialization analysis}

The overall employment dynamic in the Republic of Karelia was negative. The total number of people employed decreased by $17.42 \%$, or by 40,822 people over eight years. Analyzing employment statistics of the Republic of Karelia during the period of 2009-2016, we detected four clusters: Transportation and Logistics, Maritime, Paper Products, and Furniture, which received at least one star. Detailed results are presented in Table 7.

The Republic of Karelia had a low specialization level in Transportation and Logistics, and the critical mass of this cluster was steadily decreasing during the analyzed period. After an $8.15 \%$ decrease of the cluster's employment in 2010-2011, there was a slight growth of the cluster's critical mass from 23,972 up to 24,285 people employed; that is, by $1.31 \%$ in 2013 compared to 2012. After that, there was a stable decrease in the Transportation and Logistics cluster's critical mass: 18.04\% in 2016 compared to 2012. Therefore, the long-term decrease of the cluster's critical mass in the Republic of Karelia was $23.74 \%$ over eight years. It resulted in the Republic of Karelia losing one star of cluster specialization in 2013, since two of the three localization measures did not fulfill the threshold requirements.

The Republic of Karelia had a low specialization in Maritime. However, the critical mass of this cluster was unstable. The region still has a certain margin of safety in relative terms, since the overall employment in Maritime activities decreased by $22.55 \%$ over eight years. However, in terms of absolute values, the region demonstrated a cyclic growth and a decrease of the critical mass by $9.01 \%$ over eight years. Nevertheless, the region gained one additional star in 2016, which can be attributed to the overall decrease of the Maritime critical mass.

Table 7. Employment based parameters of significant clusters in the Republic of Karelia

\begin{tabular}{|c|c|c|c|c|c|c|c|c|}
\hline $\begin{array}{ll}\text { Parameter } & \text { Year } \\
\end{array}$ & 2009 & 2010 & 2011 & 2012 & 2013 & 2014 & 2015 & 2016 \\
\hline$E$ (people) & 47427502 & 46719007 & 45872388 & 45898382 & 45815640 & 45486400 & 45106533 & 44446352 \\
\hline \multicolumn{9}{|c|}{ Transportation and Logistics cluster parameters } \\
\hline$E_{\tilde{i}}$ (people) & 3489740 & 3370683 & 3371228 & 3400956 & 3360962 & 3377649 & 3352174 & 3308218 \\
\hline$E_{\text {iq }}$ (people) & 26100 & 24582 & 23972 & 24285 & 23232 & 21923 & 21375 & 19903 \\
\hline$G R_{t=0}(\%)$ & & -5.82 & -8.15 & -6.95 & -10.99 & -16.00 & -18.10 & -23.74 \\
\hline Number of stars & 2 & 2 & 2 & 2 & 1 & 1 & 1 & 1 \\
\hline LQ & 1.51 & 1.49 & 1.44 & 1.45 & 1.44 & 1.40 & 1.40 & 1.38 \\
\hline Size $(\%)$ & 0.75 & 0.73 & 0.71 & 0.71 & 0.69 & 0.65 & 0.64 & 0.60 \\
\hline Focus $(\%)$ & 11.14 & 10.77 & 10.60 & 10.77 & 10.56 & 10.37 & 10.41 & 10.29 \\
\hline \multicolumn{9}{|c|}{ Maritime cluster parameters } \\
\hline
\end{tabular}




\section{ENTREPRENEURSHIP AND SUSTAINABILITY ISSUES}

ISSN 2345-0282 (online) http://jssidoi.org/jesi/ 2020 Volume 8 Number 1 (September)

http://doi.org/10.9770/jesi.2020.8.1(10)

\begin{tabular}{|c|c|c|c|c|c|c|c|c|}
\hline$E_{\text {iq }}$ (people) & 1731 & 1590 & 1628 & 1755 & 1811 & 1734 & 1623 & 1575 \\
\hline$G R_{t}(\%)$ & & -8.15 & 2.39 & 7.80 & 3.19 & -4.25 & -6.40 & -2.96 \\
\hline$G R_{t=0}(\%)$ & & -8.15 & -5.95 & 1.39 & 4.62 & 0.17 & -6.24 & $\begin{array}{l}-9.01 \\
\end{array}$ \\
\hline Number of stars & 1 & 1 & 1 & 1 & 1 & 1 & 1 & 2 \\
\hline LQ & 2.36 & 2.13 & 2.41 & 2.76 & 2.97 & 3.20 & 3.06 & 3.15 \\
\hline Size $(\%)$ & 1.17 & 1.04 & 1.19 & 1.36 & 1.43 & 1.49 & 1.39 & 1.37 \\
\hline Focus $(\%)$ & 0.74 & 0.70 & 0.72 & 0.78 & 0.82 & 0.82 & 0.79 & 0.81 \\
\hline \multicolumn{9}{|c|}{ Paper Products cluster parameters } \\
\hline$E_{\tilde{f}}($ people $)$ & 137015 & 136152 & 137499 & 136273 & 132216 & 128119 & 125839 & 130471 \\
\hline$E_{i g}($ people $)$ & 7794 & 7279 & 7156 & 7067 & 6501 & 5910 & 5604 & 5583 \\
\hline$G_{t}(\%)$ & & -6.61 & -1.69 & -1.24 & -8.01 & -9.09 & -5.18 & -0.37 \\
\hline$G R_{t=0}(\%)$ & & -6.61 & $\begin{array}{l}-8.19 \\
\end{array}$ & -9.33 & -16.59 & -24.17 & -28.10 & -28.37 \\
\hline Number of stars & 3 & 3 & 3 & 3 & 3 & 3 & 3 & 3 \\
\hline LQ & 11.51 & 10.94 & 10.56 & 10.56 & 10.24 & 9.92 & 9.78 & 9.83 \\
\hline Size (\%) & 5.69 & 5.35 & 5.20 & 5.19 & 4.92 & 4.61 & 4.45 & 4.28 \\
\hline Focus $(\%)$ & 3.33 & 3.19 & 3.16 & 3.13 & 2.95 & 2.80 & 2.73 & 2.89 \\
\hline \multicolumn{9}{|c|}{ Furniture cluster parameters } \\
\hline$E_{i}$ (people) & 314686 & 316139 & 294371 & 298059 & 294375 & 278843 & 267375 & 259033 \\
\hline$E_{\text {iq }}$ (people) & 2439 & 2329 & 1991 & 1809 & 1603 & 1418 & 1426 & 1431 \\
\hline$G R_{t}(\%)$ & & -4.51 & -14.51 & -9.14 & -11.39 & -11.54 & 0.56 & 0.35 \\
\hline$G R_{t=0}(\%)$ & & -4.51 & -18.37 & -25.83 & -34.28 & -41.86 & -41.53 & -41.33 \\
\hline Number of stars & 1 & 1 & 1 & 0 & 0 & 0 & 0 & 0 \\
\hline LQ & 1.57 & 1.51 & 1.37 & 1.24 & 1.13 & 1.09 & 1.17 & 1.27 \\
\hline Size (\%) & 0.78 & 0.74 & 0.68 & 0.61 & 0.54 & 0.51 & 0.53 & 0.55 \\
\hline Focus $(\%)$ & 1.04 & 1.02 & 0.88 & 0.80 & 0.73 & 0.67 & 0.69 & 0.74 \\
\hline
\end{tabular}

The Republic of Karelia had a high specialization level in Paper Products and the critical mass of its cluster was strongly decreasing during the period of 2009-2016. The overall decrease of the cluster's critical mass was $28.37 \%$ over eight years. In addition, the decrease of the Paper Products cluster's critical mass in the Republic of Karelia was significantly higher than the overall decrease of the Paper Products cluster's critical mass, being $27.61 \%$ compared to $4.78 \%$. It led to a decrease in the cluster localization parameters, but it did not result in losing the specialization, since three localization measures out of three fulfilled the threshold requirements.

The Republic of Karelia lost specialization in Furniture Production in 2012, since the cluster's critical mass decreased by $41.33 \%$ over eight years, while the cluster's overall critical mass went down by only $17.69 \%$. The breakpoint was in 2011-2012, when LQ did not fulfill the threshold requirements, along with Focus and Size.

Therefore, the Republic of Karelia was highly specialized only in one type of activity-Paper Products. However, the critical mass of this cluster greatly decreased during the analyzed period. In addition, the region had a low specialization in two other types of activities: Transportation and Logistics, which showed a decrease of the critical mass, and Maritime, the critical mass of which was unstable. In one type of activity, the region showed lack of specialization due to the continuously steady decrease in its critical mass.

\section{Krasnoyarsk Krai cluster specialization analysis}

The overall employment dynamic in Krasnoyarsk Krai was negative. The total number of employed people decreased by $6.15 \%$, or by 64,833 people over eight years. Analyzing the employment statistics in Krasnoyarsk Krai during the period of 2009-2016, we detected four clusters: Transportation and Logistics, Business Services, and Entertainment and Production Technology, which received at least one star. Detailed results are presented in Table 8. 


\section{ENTREPRENEURSHIP AND SUSTAINABILITY ISSUES}

ISSN 2345-0282 (online) http://jssidoi.org/jesi/ 2020 Volume 8 Number 1 (September)

http://doi.org/10.9770/jesi.2020.8.1(10)

Table 8. Employment-based parameters of significant clusters in Krasnoyarsk Krai

\begin{tabular}{|c|c|c|c|c|c|c|c|c|}
\hline Parameter $\quad$ Year & 2009 & 2010 & 2011 & 2012 & 2013 & 2014 & 2015 & 2016 \\
\hline \multicolumn{9}{|c|}{ General employment parameters } \\
\hline$E$ (people) & 47427502 & 46719007 & 45872388 & 45898382 & 45815640 & 45486400 & 45106533 & 44446352 \\
\hline$E_{q}$ (people) & 1054055 & 1056537 & 1049084 & 1056420 & 1042109 & 1046767 & 1021040 & 989222 \\
\hline \multicolumn{9}{|c|}{ Transportation and Logistics cluster parameters } \\
\hline$E_{\tilde{i}}$ (people) & 3489740 & 3370683 & 3371228 & 3400956 & 3360962 & 3377649 & 3352174 & 3308218 \\
\hline$E_{i q}$ (people) & 89985 & 88687 & 89832 & 91984 & 91829 & 92266 & 91374 & 90767 \\
\hline$G R_{t}(\%)$ & & -1.44 & 1.29 & 2.40 & -0.17 & 0.48 & -0.97 & -0.66 \\
\hline$G R_{t=0}(\%)$ & & -1.44 & -0.17 & 2.22 & 2.05 & 2.53 & 1.54 & 0.87 \\
\hline Number of stars & 1 & 1 & 1 & 1 & 1 & 1 & 1 & 1 \\
\hline LQ & 1.16 & 1.16 & 1.17 & 1.18 & 1.20 & 1.19 & 1.20 & 1.23 \\
\hline Size (\%) & 2.58 & 2.63 & 2.66 & 2.70 & 2.73 & 2.73 & 2.73 & 2.74 \\
\hline Focus $(\%)$ & 8.54 & 8.39 & 8.56 & 8.71 & 8.81 & 8.81 & 8.95 & 9.18 \\
\hline \multicolumn{9}{|c|}{ Business Services cluster parameters } \\
\hline$E_{i}$ (people) & 2969478 & 2921201 & 2880799 & 3146203.9 & 3237312 & 3272631.1 & 3257275.3 & 3189467 \\
\hline$E_{i q}$ (people) & 74557 & 73045 & 75263 & 83302 & 83352 & 86755 & 81563 & 74253 \\
\hline$G R_{t}(\%)$ & & -2.03 & 3.04 & 10.68 & 0.06 & 4.08 & -5.98 & -8.96 \\
\hline$G R_{t=0}(\%)$ & & -2.03 & 0.95 & 11.73 & 11.80 & 16.36 & 9.40 & -0.41 \\
\hline Number of stars & 0 & 0 & 0 & 1 & 0 & 1 & 0 & 0 \\
\hline LQ & 1.13 & 1.11 & 1.14 & 1.15 & 1.13 & 1.15 & 1.11 & 1.05 \\
\hline Size (\%) & 2.51 & 2.50 & 2.61 & 2.65 & 2.57 & 2.65 & 2.50 & 2.33 \\
\hline Focus $(\%)$ & 7.07 & 6.91 & 7.17 & 7.89 & 8.00 & 8.29 & 7.99 & 7.51 \\
\hline \multicolumn{9}{|c|}{ Entertainment cluster parameters } \\
\hline$E_{\tilde{I}}($ people $)$ & 1134931 & 1096820 & 1076443 & 1087827.8 & 1067113.6 & 1027259 & 1014388 & 1010873 \\
\hline$E_{i q}$ (people) & 28162 & 28338 & 29061 & 29185 & 29604 & 29723 & 29290 & 28870 \\
\hline$G R_{t}(\%)$ & & 0.62 & 2.55 & 0.43 & 1.44 & 0.40 & -1.46 & -1.43 \\
\hline$G R_{t=0}(\%)$ & & 0.62 & 3.19 & 3.63 & 5.12 & 5.54 & 4.01 & 2.51 \\
\hline Number of stars & 1 & 1 & 1 & 1 & 1 & 1 & 2 & 2 \\
\hline $\mathbf{L Q}$ & 1.12 & 1.14 & 1.18 & 1.17 & 1.22 & 1.26 & 1.28 & 1.28 \\
\hline Size (\%) & 2.48 & 2.58 & 2.70 & 2.68 & 2.77 & 2.89 & 2.89 & 2.86 \\
\hline Focus $(\%)$ & 2.67 & 2.68 & 2.77 & 2.76 & 2.84 & 2.84 & 2.87 & 2.92 \\
\hline \multicolumn{9}{|c|}{ Production Technology cluster parameters } \\
\hline$E_{\tilde{i}}$ (people) & 630556 & 608180 & 619596 & 614537 & 602202 & 587375.7 & 571254 & 545333 \\
\hline$E_{i q}$ (people) & 20539 & 20599 & 19981 & 20140 & 19771 & 19170 & 19031 & 19658 \\
\hline$G R_{t}(\%)$ & & 0.29 & -3.00 & 0.80 & -1.83 & -3.04 & -0.73 & 3.29 \\
\hline$G R_{t=0}(\%)$ & & 0.29 & -2.72 & -1.94 & -3.74 & -6.67 & -7.34 & -4.29 \\
\hline Number of stars & 1 & 2 & 1 & 1 & 1 & 1 & 2 & 2 \\
\hline LQ & 1.47 & 1.50 & 1.41 & 1.42 & 1.44 & 1.42 & 1.47 & 1.62 \\
\hline Size $(\%)$ & 3.26 & 3.39 & 3.22 & 3.28 & 3.28 & 3.26 & 3.33 & 3.60 \\
\hline Focus $(\%)$ & 1.95 & 1.95 & 1.90 & 1.91 & 1.90 & 1.83 & 1.86 & 1.99 \\
\hline
\end{tabular}

Krasnoyarsk Krai had a low specialization level in Transportation and Logistics. However, the critical mass of this cluster was stable during the analyzed period. In the long-term, the critical mass of the cluster increased by $0.87 \%$; that is, by 782 people employed. In addition, the overall employment in the Transportation and Logistics cluster decreased by $5.2 \%$. In total, it resulted in a slight increase of the relative localization measures of this cluster. However, it was not enough for significant strengthening of the regional specialization in this type of activity.

The specialization of Krasnoyarsk Krai in Business Services was detected in 2012 and 2014, when a sudden increase in employment levels resulted in a growth of the Business Services cluster localization. However, it was 


\section{ENTREPRENEURSHIP AND SUSTAINABILITY ISSUES}

ISSN 2345-0282 (online) http://jssidoi.org/jesi/

2020 Volume 8 Number 1 (September)

http://doi.org/10.9770/jesi.2020.8.1(10)

a short-term increase which did not allow the region to strengthen its specialization over a long-term period. Therefore, the long-term decrease of the cluster's critical mass in Krasnoyarsk Krai was $0.41 \%$.

Krasnoyarsk Krai had low specialization in Entertainment activities, which demonstrated a stable critical mass. In the long term, the critical mass of the Entertainment cluster grew by $2.51 \%$; that is, 708 people. However, during the analyzed period there was a growth stage - from 2009 to 2014, the critical mass increased by 5.54\%-and a decrease stage-from 2014 to 2016, it decreased by 2.87\%. In addition, the overall employment in the Entertainment cluster decreased by $10.93 \%$; that is, by 124,058 people employed. Due to this situation, the relative specialization of the region in Entertainment increased during 2015-2016 from one to two stars, since two of the three localization measures fulfilled the threshold requirements.

Krasnoyarsk Krai had low specialization in Production Technology, which was demonstrated by the stable state of its critical mass. In the long term, the critical mass of the Production Technology cluster decreased by 4.29\%; that is, by 881 people employed. Nevertheless, with the overall employment of the Production Technology cluster decreasing by $13.52 \%$ (i.e. by 85,223 people employed), the relative specialization of the region in this type of activity grew in 2015 , since two of three localization parameters fulfilled the threshold values.

Therefore, Krasnoyarsk Krai did not have high specialization in any type of activity. However, there are three groups of activities in which this region had low specialization: Transportation and Logistics, Entertainment, and Production Technology. All three clusters demonstrated a stable condition of their critical mass. In Business Services, the region had no specialization, since the critical mass of this cluster was too low.

\section{Arkhangelsk Oblast (including Nenets AO) cluster specialization analysis}

The overall employment dynamic in Arkhangelsk Oblast was negative. The total number of people employed decreased by $11.44 \%$, or by 50,660 people over eight years. Analyzing Arkhangelsk Oblast employment statistics during the period of 2009-2016, we detected four clusters: Transportation and Logistics, Maritime, Paper Products, and Furniture, which received at least one star. Detailed results are presented in Table 9.

Arkhangelsk Oblast had a medium specialization level in Transportation and Logistics, and the critical mass of this cluster was unstable during the analyzed period. The long-term decrease of the cluster's critical mass over eight years was 5.94\%; that is, 4,392 people employed. However, the overall specialization of the region in this type of activity increased, since the employment of the whole cluster also decreased by $5.2 \%$, or by 181,522 people employed.

Arkhangelsk Oblast had low specialization in Maritime. However, the critical mass of this cluster decreased by $31.68 \%$, or by 1,195 people during the analyzed period. The decline of this cluster was faster at the regional level than at the country level, meaning that the region was losing both its relative and absolute specialization in this type of activity.

Arkhangelsk Oblast had a high specialization level in Paper Products, and the critical mass of its cluster was strongly decreasing during the period of 2009-2016. The overall decrease of the cluster's critical mass was $24.81 \%$; that is, by 2,268 people employed over eight years. In addition, the decrease of the critical mass of the Paper Products cluster in Arkhangelsk Oblast was significantly higher than the overall decrease of the critical mass of the Paper Products cluster, being $24.81 \%$ compared to 4.78\%. It resulted in Arkhangelsk Oblast losing specialization in this type of activity. However, it still had a certain margin of safety, since all three localization parameters fulfilled the threshold conditions. 


\section{ENTREPRENEURSHIP AND SUSTAINABILITY ISSUES}

ISSN 2345-0282 (online) http://jssidoi.org/jesi/ 2020 Volume 8 Number 1 (September)

http://doi.org/10.9770/jesi.2020.8.1(10)

Table 9. Employment-based parameters of significant clusters in Arkhangelsk Oblast (including Nenets AO)

\begin{tabular}{|c|c|c|c|c|c|c|c|c|}
\hline Parameter Year & 2009 & 2010 & 2011 & 2012 & 2013 & 2014 & 2015 & 2016 \\
\hline \multicolumn{9}{|c|}{ General employment parameters } \\
\hline$E$ (people) & 47427502 & 46719007 & 45872388 & 45898382 & 45815640 & 45486400 & 45106533 & 44446352 \\
\hline$E_{q}($ people $)$ & 442903 & 433931 & 436355 & 418786.1 & 409795 & 405572.6 & 399017 & 392243.2 \\
\hline \multicolumn{9}{|c|}{ Transportation and Logistics cluster parameters } \\
\hline$E_{\tilde{i}}$ (people) & 3489740 & 3370683 & 3371228 & 3400956 & 3360962 & 3377649 & 3352174 & 3308218 \\
\hline$E_{i q}$ (people) & 73878 & 71412 & 72084 & 68609 & 67490 & 67275 & 68010 & 69486 \\
\hline$G R_{t}(\%)$ & & -3.34 & 0.94 & -4.82 & -1.63 & -0.32 & 1.09 & 2.17 \\
\hline$G R_{t=0}(\%)$ & & -3.34 & -2.43 & -7.13 & -8.65 & -8.94 & -7.94 & -5.94 \\
\hline Number of stars & 2 & 2 & 2 & 2 & 2 & 2 & 2 & 2 \\
\hline LQ & 2.27 & 2.28 & 2.25 & 2.21 & 2.25 & 2.23 & 2.29 & 2.38 \\
\hline Size (\%) & 2.12 & 2.12 & 2.14 & 2.02 & 2.01 & 1.99 & 2.03 & 2.10 \\
\hline Focus $(\%)$ & 16.68 & 16.46 & 16.52 & 16.38 & 16.47 & 16.59 & 17.04 & 17.72 \\
\hline \multicolumn{9}{|c|}{ Maritime cluster parameters } \\
\hline$E_{\tilde{i}}$ (people) & 148225 & 152423 & 136905 & 129441.6 & 126963 & 116436.8 & 116557 & 114799 \\
\hline$E_{\text {iq }}$ (people) & 3772 & 3802 & 3949 & 3701 & 3192 & 2568 & 2554 & 2577 \\
\hline$G R_{t}(\%)$ & & 0.80 & 3.87 & -6.28 & -13.75 & -19.55 & -0.55 & 0.90 \\
\hline$G R_{t=0}(\%)$ & & 0.80 & 4.69 & -1.88 & -15.38 & -31.92 & -32.29 & -31.68 \\
\hline Number of stars & 1 & 1 & 1 & 2 & 1 & 1 & 1 & 1 \\
\hline LQ & 2.73 & 2.69 & 3.03 & 3.13 & 2.81 & 2.47 & 2.48 & 2.54 \\
\hline Size $(\%)$ & 2.54 & 2.49 & 2.88 & 2.86 & 2.51 & 2.21 & 2.19 & 2.24 \\
\hline Focus $(\%)$ & 0.85 & 0.88 & 0.90 & 0.88 & 0.78 & 0.63 & 0.64 & 0.66 \\
\hline \multicolumn{9}{|c|}{ Paper Products cluster parameters } \\
\hline$E_{\tilde{i}}($ people $)$ & 137015 & 136152 & 137499 & 136273 & 132216 & 128119 & 125839 & 130471 \\
\hline$E_{i q}$ (people) & 9141 & 8578 & 8548 & 8308 & 7778 & 7448 & 7012 & 6873 \\
\hline$G R_{t}(\%)$ & & -6.16 & -0.35 & -2.81 & -6.38 & -4.24 & -5.85 & -1.98 \\
\hline$G R_{t=0}(\%)$ & & -6.16 & -6.49 & -9.11 & -14.91 & -18.52 & -23.29 & -24.81 \\
\hline Number of stars & 3 & 3 & 3 & 3 & 3 & 3 & 3 & 3 \\
\hline $\mathbf{L Q}$ & 7.14 & 6.78 & 6.54 & 6.68 & 6.58 & 6.52 & 6.30 & 5.97 \\
\hline Size $(\%)$ & 6.67 & 6.30 & 6.22 & 6.10 & 5.88 & 5.81 & 5.57 & 5.27 \\
\hline Focus (\%) & 2.06 & 1.98 & 1.96 & 1.98 & 1.90 & 1.84 & 1.76 & 1.75 \\
\hline \multicolumn{9}{|c|}{ Furniture cluster parameters } \\
\hline$E_{\tilde{i}}$ (people) & 314686 & 316139 & 294371 & 298059 & 294375 & 278843 & 267375 & 259033 \\
\hline$E_{\text {iq }}$ (people) & 5145 & 4776 & 4429 & 4122 & 3566 & 3450 & 3492 & 2935 \\
\hline$G R_{t}(\%)$ & & -7.17 & -7.27 & -6.93 & -13.49 & -3.25 & 1.22 & -15.95 \\
\hline$G R_{t=0}(\%)$ & & -7.17 & -13.92 & -19.88 & -30.69 & -32.94 & -32.13 & -42.95 \\
\hline Number of stars & 1 & 1 & 1 & 0 & 0 & 0 & 0 & 0 \\
\hline LQ & 1.75 & 1.63 & 1.58 & 1.52 & 1.35 & 1.39 & 1.48 & 1.28 \\
\hline Size (\%) & 1.63 & 1.51 & 1.50 & 1.38 & 1.21 & 1.24 & 1.31 & 1.13 \\
\hline Focus $(\%)$ & 1.16 & 1.10 & 1.01 & 0.98 & 0.87 & 0.85 & 0.88 & 0.75 \\
\hline
\end{tabular}

Therefore, Arkhangelsk Oblast, in total, had clusters with decreasing critical mass, which resulted, in some cases, in a rise in relative specializations, but a decrease in absolute values.

Arkhangelsk Oblast lost specialization in Furniture Production in 2012, since the critical mass of the cluster in Arkhangelsk Oblast decreased by $42.95 \%$; that is, by 2,210 people over eight years. Meanwhile, the overall critical mass of the cluster decreased by only 17.69\%. The breakpoint was in 2011-2012, when LQ fulfilled neither of the threshold requirements, nor did Focus or Size. 


\section{ENTREPRENEURSHIP AND SUSTAINABILITY ISSUES}

ISSN 2345-0282 (online) http://jssidoi.org/jesi/ 2020 Volume 8 Number 1 (September) http://doi.org/10.9770/jesi.2020.8.1(10)

\section{Khanty-Mansi AO cluster specialization analysis}

The overall employment dynamic in Khanty-Mansi AO was negative. The total number of people employed decreased by $2.18 \%$, or by 16,772 people over eight years. Analyzing employment statistics in Khanty-Mansi AO during the period of 2009-2016, we detected three clusters: Transportation and Logistics, Oil and Gas, and Construction, which received at least one star. Detailed results are presented in Table 10.

Khanty-Mansi AO lost specialization in Furniture Production in 2010, since the cluster's critical mass decreased by $13.93 \%$; that is, by 9617 people over eight years. Meanwhile, the cluster's overall critical mass decreased by only $5.2 \%$. Therefore, the region was steadily losing its specialization in this type of activity due to the decrease of the cluster's critical mass.

Table 10. Employment-based parameters of significant clusters in Khanty-Mansi AO

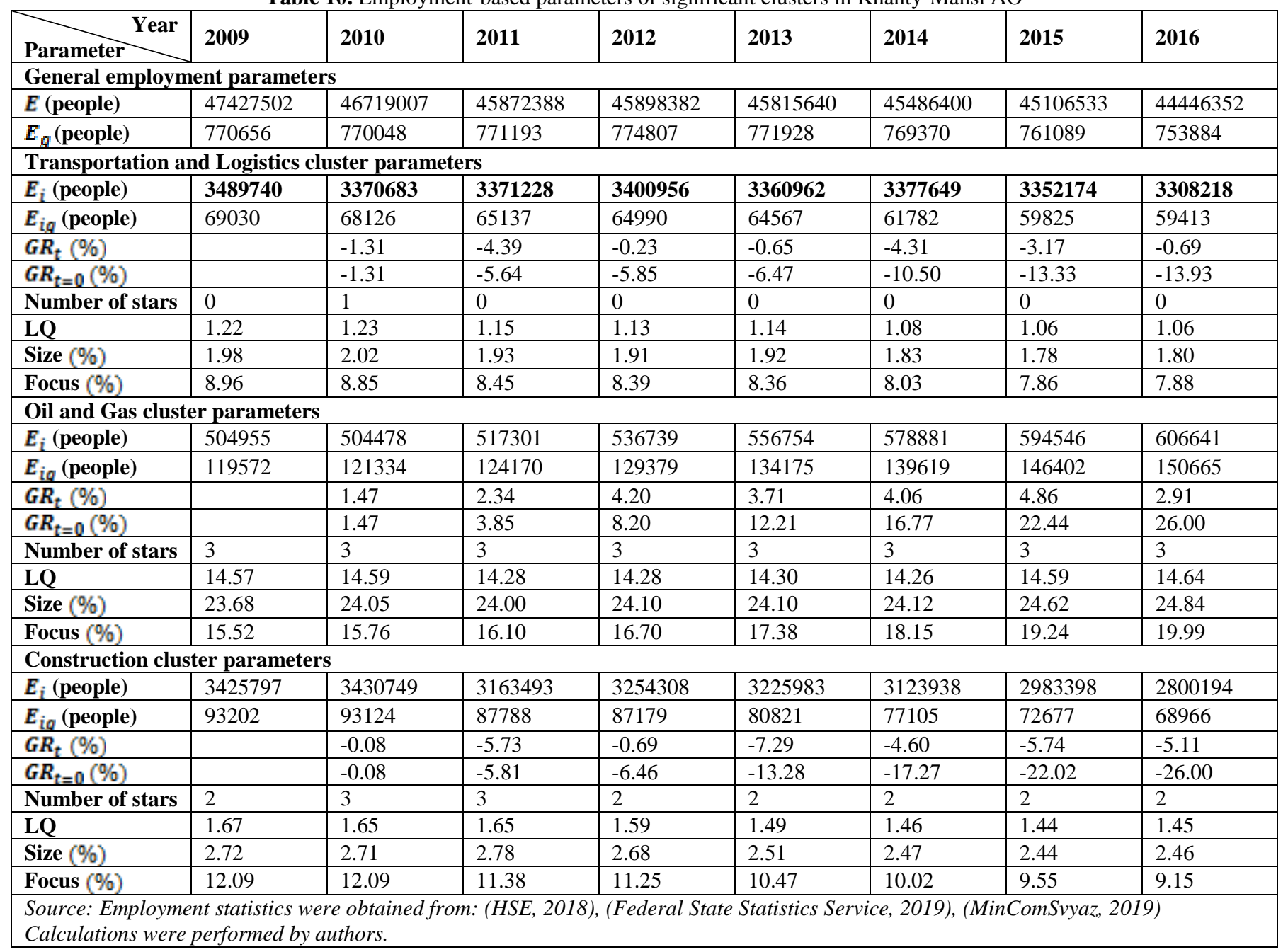

Khanty-Mansi AO had a high specialization level in Oil and Gas, and the critical mass of this cluster was growing significantly during the analyzed period. The overall increase of the cluster's critical mass was $26 \%$ over eight years. This resulted in the strengthening of the cluster's specialization and its stabilization at a high level, since three localization measures out of three fulfilled the threshold requirements. 


\section{ENTREPRENEURSHIP AND SUSTAINABILITY ISSUES}

ISSN 2345-0282 (online) http://jssidoi.org/jesi/ 2020 Volume 8 Number 1 (September)

http://doi.org/10.9770/jesi.2020.8.1(10)

Khanty-Mansi AO had a medium specialization level in Construction and the critical mass of this cluster was greatly decreasing during the analyzed period. The long-term decrease of the cluster's critical mass was $26 \%$, or 24,236 people employed. Nevertheless, the specialization of Khanty-Mansi AO in Construction remains at a high level, despite the fact that it is constantly decreasing.

We identified three clusters in Khanty-Mansi AO: Transportation and Logistics, Oil and Gas, and Construction. Only the Oil and Gas cluster showed strong growth of its critical mass, while the other two clusters were decreasing in terms of the number of people employed.

\section{Murmansk Oblast cluster specialization analysis}

The overall employment dynamic in Murmansk Oblast was negative. The total number of people employed decreased by $11.11 \%$, or by 34,409 people employed over eight years. Analyzing employment statistics in Murmansk Oblast during the period of 2009-2016, we detected two clusters: Transportation and Logistics and Maritime, which have received at least one star. Detailed results are presented in Table 11.

Table 11. Employment-based parameters of significant clusters in Murmansk Oblast

\begin{tabular}{|c|c|c|c|c|c|c|c|c|}
\hline $\begin{array}{ll}\text { Parameter } & \text { Year } \\
\end{array}$ & 2009 & 2010 & 2011 & 2012 & 2013 & 2014 & 2015 & 2016 \\
\hline \multicolumn{9}{|c|}{ General employment parameters } \\
\hline$E$ (people) & 47427502 & 46719007 & 45872388 & 45898382 & 45815640 & 45486400 & 45106533 & 44446352 \\
\hline$E_{g}$ (people) & 309727 & 301079 & 300264 & 300209 & 296615 & 288905 & 281950 & 275318 \\
\hline \multicolumn{9}{|c|}{ Transportation and logistics cluster parameters } \\
\hline$E_{i}($ people $)$ & 3489740 & 3370683 & 3371228 & 3400956 & 3360962 & 3377649 & 3352174 & 3308218 \\
\hline$E_{\text {ig }}$ (people) & 47243 & 44929 & 42501 & 41274 & 40302 & 38585 & 37209 & 36936 \\
\hline$G R_{\varepsilon}(\%)$ & & -4.90 & -5.40 & -2.89 & -2.35 & -4.26 & -3.57 & -0.73 \\
\hline$G R_{t=0}(96)$ & & -4.90 & -10.04 & -12.63 & -14.69 & -18.33 & -21.24 & -21.82 \\
\hline Number of stars & 2 & 2 & 2 & 2 & 2 & 2 & 2 & 2 \\
\hline LQ & 2.07 & 2.07 & 1.93 & 1.86 & 1.85 & 1.80 & 1.78 & 1.80 \\
\hline Size (96) & 1.35 & 1.33 & 1.26 & 1.21 & 1.20 & 1.14 & 1.11 & 1.12 \\
\hline Focus $(96)$ & 15.25 & 14.92 & 14.15 & 13.75 & 13.59 & 13.36 & 13.20 & 13.42 \\
\hline \multicolumn{9}{|c|}{ Maritime cluster parameters } \\
\hline$E_{i}$ (people) & 148225 & 152423 & 136905 & 129441.6 & 126963 & 116436.8 & 116557 & 114799 \\
\hline$E_{\text {igg }}$ (people) & 8734 & 8016 & 7464 & 7834 & 7466 & 7170 & 6832 & 6321 \\
\hline$G R_{f}(96)$ & & -8.22 & -6.89 & 4.96 & -4.70 & -3.96 & -4.71 & -7.48 \\
\hline$G R_{t=0}(96)$ & & -8.22 & -14.54 & -10.30 & -14.52 & -17.91 & -21.78 & -27.63 \\
\hline Number of stars & 3 & 3 & 3 & 3 & 3 & 3 & 3 & 3 \\
\hline LQ & 9.02 & 8.16 & 8.33 & 9.25 & 9.08 & 9.70 & 9.38 & 8.89 \\
\hline Size $(96)$ & 5.89 & 5.26 & 5.45 & 6.05 & 5.88 & 6.16 & 5.86 & 5.51 \\
\hline Focus $(96)$ & 2.82 & 2.66 & 2.49 & 2.61 & 2.52 & 2.48 & 2.42 & 2.30 \\
\hline
\end{tabular}

Murmansk Oblast had a medium specialization level in Transportation and Logistics, and the critical mass of this cluster was steadily decreasing during the analyzed period. The overall decrease of the critical mass of the Transportation and Logistics cluster located in Murmansk Oblast was 21.82\%; that is, 10,307 people employed over eight years. Therefore, all three localization parameters of the cluster decreased. Nevertheless, its specialization remains at the level of two stars.

Murmansk Oblast had a high specialization level in Maritime, and the critical mass of its cluster was steadily decreasing during the period of 2009-2016. The overall decrease of the cluster's critical mass was $27.63 \%$ over eight years. In addition, the decrease of the Maritime cluster's critical mass in Murmansk Oblast was higher than the overall decrease of the Maritime cluster's critical mass, being $27.63 \%$ compared to $22.55 \%$. It resulted in Murmansk Oblast decreasing in overall specialization in this type of activity in the long run. 
ISSN 2345-0282 (online) http://jssidoi.org/jesi/ 2020 Volume 8 Number 1 (September) http://doi.org/10.9770/jesi.2020.8.1(10)

Therefore, there are only two significant clusters in the Murmansk region: Transportation and Logistics and Maritime. The critical masses of both clusters were steadily decreasing during the analyzed period. Consequently, the region lost its specialization and should promote new core activities, which can be part of its long-term development.

\section{Sakha Republic cluster specialization analysis}

The overall employment dynamic in Sakha Republic was negative. The total number of people employed decreased by $6.22 \%$, or by 22,722 people employed over eight years. Analyzing the employment statistics in Sakha Republic during the period of 2009-2016, we detected two clusters: Entertainment and Oil and Gas, which have received at least one star. Detailed results are presented in Table 12.

Sakha Republic had not had a specialization level in Oil and Gas until 2011. Due to a significant growth of the cluster's critical mass over a long-term period of 3,535 people employed, or $83.65 \%$, one of the localization parameters fulfilled the threshold requirement and the region received one star in this type of activity. Therefore, the region has a potential for strengthening its specialization if the critical mass continues to grow.

Sakha Republic had a low specialization in Entertainment; the critical mass of this cluster was at a stable level. The long-term change of the critical mass was negative. It declined by $3.49 \%$, or 432 people over eight years.

Table 12. Employment-based parameters of significant clusters in Sakha Republic

\begin{tabular}{|c|c|c|c|c|c|c|c|c|}
\hline $\begin{array}{l}\text { Year } \\
\text { Parameter }\end{array}$ & 2009 & 2010 & 2011 & 2012 & 2013 & 2014 & 2015 & 2016 \\
\hline$E$ (people) & 47427502 & 46719007 & 45872388 & 45898382 & 45815640 & 45486400 & 45106533 & 44446352 \\
\hline \multicolumn{9}{|c|}{ Oil and Gas cluster parameters } \\
\hline$E_{\tilde{i}}$ (people) & 504955 & 504478 & 517301 & 536739 & 556754 & 578881 & 594546 & 606641 \\
\hline$E_{i g}$ (people) & 4226 & 3836 & 6529 & 7120 & 7043 & 7209 & 7313 & 7761 \\
\hline Number of stars & 0 & 0 & 1 & 1 & 1 & 1 & 1 & 1 \\
\hline LQ & 1.09 & 1.01 & 1.63 & 1.72 & 1.65 & 1.62 & 1.61 & 1.66 \\
\hline Size $(\%)$ & 0.84 & 0.76 & 1.26 & 1.33 & 1.27 & 1.25 & 1.23 & 1.28 \\
\hline Focus $(\%)$ & 1.16 & 1.09 & 1.84 & 2.01 & 2.01 & 2.07 & 2.12 & 2.27 \\
\hline \multicolumn{9}{|c|}{ Entertainment cluster parameters } \\
\hline Number of stars & 1 & 1 & 1 & 1 & 1 & 1 & 1 & 1 \\
\hline $\mathbf{L Q}$ & 1.42 & 1.47 & 1.46 & 1.50 & 1.51 & 1.53 & 1.55 & 1.53 \\
\hline Size $(\%)$ & 1.09 & 1.11 & 1.13 & 1.16 & 1.16 & 1.17 & 1.18 & 1.18 \\
\hline Focus $(\%)$ & 3.39 & 3.46 & 3.42 & 3.55 & 3.51 & 3.46 & 3.48 & 3.49 \\
\hline
\end{tabular}

Therefore, Sakha Republic has a potential for strengthening its specialization in Oil and Gas and Entertainment activities. 


\section{ENTREPRENEURSHIP AND SUSTAINABILITY ISSUES}

ISSN 2345-0282 (online) http://jssidoi.org/jesi/ 2020 Volume 8 Number 1 (September) http://doi.org/10.9770/jesi.2020.8.1(10)

\section{Chukotka AO cluster specialization analysis}

The overall employment dynamics in Chukotka AO was negative. The total number of people employed decreased by $9.72 \%$, or by 2,946 people employed over eight years. Analyzing the employment statistics in Chukotka AO during the period of 2009-2016, we did not detected any clusters which could receive at least one star. The general results of the employment dynamics are presented in Table 13.

Table 13. Employment-based parameters of significant clusters in Chukotka AO

\begin{tabular}{|l|l|l|l|l|l|l|l|l|}
\hline Yarameter Year & $\mathbf{2 0 0 9}$ & $\mathbf{2 0 1 0}$ & $\mathbf{2 0 1 1}$ & $\mathbf{2 0 1 2}$ & $\mathbf{2 0 1 3}$ & $\mathbf{2 0 1 4}$ & $\mathbf{2 0 1 5}$ & $\mathbf{2 0 1 6}$ \\
\hline Genera employment parameters \\
\hline$E$ (people) & 47427502 & 46719007 & 45872388 & 45898382 & 45815640 & 45486400 & 45106533 & 44446352 \\
\hline$E_{5}$ (people) & 30300 & 30055 & 29914 & 29494 & 28983 & 27902 & 27758 & 27354 \\
\hline
\end{tabular}

Source: Combined results of the Russian regions cluster parameters analysis

Table 14 gives an analytical interpretation of the computational results presented earlier. The table includes only those clusters which were significant in at least in one Arctic region. Therefore, nine clusters out of 37 are presented. Boxes with the symbol «-» in Table 14 refer to the unidentified (insignificant) clusters. We did not mark them in order to make it clearer for analysis. Other boxes include the characteristic of the cluster in a specific region in accordance with the classification, presented in Section 2.1.

Tables 14 and 15 provide some valuable insights concerning the overall situation in the Russian Arctic regions. The first insight is that the overall state of the most typical significant clusters for these regions is not satisfactory, since there is only one significant cluster which achieved a steady growth. We can see that, in general, employment in such clusters as «Transportation and Logistics», «Maritime», «Paper Products», "Construction», «Entertainment», and «Furniture» was mostly either decreasing or unstable, which means that these clusters were steadily declining in a long term perspective during the analyzed period. On the other hand, the only significant cluster which achieved a steady growth in all regions where it was present was the "Oil and Gas» cluster. The second insight refers to the overall cluster structure of the Russian Arctic region. A majority of clusters in Russian Arctic regions are not significant, meaning that there are relatively too few employees. Therefore, the localization of these clusters is slightly above average, which is not enough for generating positive spillovers or organizing export activities. These two insights can potentially become a basis for elaborating a policy which will slow down the decrease of the discussed clusters and, consequently, support diversification and specialization of the economy, since it is associated with positive spillover effects.

Table 14. State of development of identified clusters in Russian arctic regions for 2009-2016

\begin{tabular}{|c|c|c|c|c|c|c|c|c|c|}
\hline $\begin{array}{l}\text { Region } \\
\text { Cluster }\end{array}$ & $\begin{array}{c}\text { Komi } \\
\text { Republic }\end{array}$ & $\begin{array}{l}\text { Yamalo- } \\
\text { Nenets } \\
\text { AO }\end{array}$ & $\begin{array}{c}\text { Republic } \\
\text { of } \\
\text { Karelia }\end{array}$ & $\begin{array}{c}\text { Krasnoyarsk } \\
\text { Krai }\end{array}$ & $\begin{array}{c}\text { Arkhangelsk } \\
\text { Oblast } \\
\text { including } \\
\text { Nenets AO }\end{array}$ & $\begin{array}{c}\text { Khanty- } \\
\text { Mansi } \\
\text { AO }\end{array}$ & $\begin{array}{c}\text { Murmansk } \\
\text { Oblast }\end{array}$ & $\begin{array}{c}\text { Sakha } \\
\text { Republic }\end{array}$ & $\begin{array}{c}\text { Chukotka } \\
\text { AO }\end{array}$ \\
\hline $\begin{array}{l}\text { Transportation } \\
\text { and Logistics }\end{array}$ & $\begin{array}{l}\text { Medium } \\
\text { spec. } \\
\text { Unstable }\end{array}$ & $\begin{array}{l}\text { Medium } \\
\text { spec. } \\
\text { Unstable }\end{array}$ & $\begin{array}{c}\text { Low } \\
\text { spec. } \\
\text { Strong } \\
\text { decrease }\end{array}$ & $\begin{array}{c}\text { Low spec. } \\
\text { Stable }\end{array}$ & $\begin{array}{l}\text { Medium } \\
\text { spec. } \\
\text { Unstable }\end{array}$ & $\begin{array}{c}\text { No spec. } \\
\text { Strong } \\
\text { decrease }\end{array}$ & $\begin{array}{l}\text { Medium } \\
\text { spec. } \\
\text { Strong } \\
\text { decrease }\end{array}$ & - & - \\
\hline Maritime & & $\begin{array}{c}\text { Low } \\
\text { spec. } \\
\text { Strong } \\
\text { decrease }\end{array}$ & $\begin{array}{c}\text { Low } \\
\text { spec. } \\
\text { Unstable }\end{array}$ & - & $\begin{array}{l}\text { Low spec. } \\
\text { Strong } \\
\text { decrease }\end{array}$ & - & $\begin{array}{c}\text { High spec. } \\
\text { Strong } \\
\text { decrease }\end{array}$ & - & - \\
\hline
\end{tabular}


ENTREPRENEURSHIP AND SUSTAINABILITY ISSUES

ISSN 2345-0282 (online) http://jssidoi.org/jesi/ 2020 Volume 8 Number 1 (September) http://doi.org/10.9770/jesi.2020.8.1(10)

\begin{tabular}{|c|c|c|c|c|c|c|c|c|c|}
\hline Oil and Gas & $\begin{array}{c}\text { High spec } \\
\text { Strong } \\
\text { growth }\end{array}$ & $\begin{array}{l}\text { High } \\
\text { spec. } \\
\text { Strong } \\
\text { growth }\end{array}$ & - & - & - & $\begin{array}{l}\text { High } \\
\text { spec. } \\
\text { Strong } \\
\text { growth }\end{array}$ & - & $\begin{array}{c}\text { No spec. } \\
\text { Strong } \\
\text { growth }\end{array}$ & - \\
\hline Construction & $\begin{array}{l}\text { No spec. } \\
\text { Unstable }\end{array}$ & $\begin{array}{l}\text { Medium } \\
\text { spec. } \\
\text { Unstable }\end{array}$ & - & - & - & $\begin{array}{c}\text { Medium } \\
\text { spec. } \\
\text { Strong } \\
\text { decrease }\end{array}$ & - & - & - \\
\hline Entertainment & & - & - & $\begin{array}{l}\text { Low spec. } \\
\text { Stable }\end{array}$ & - & - & - & $\begin{array}{l}\text { Low } \\
\text { spec. } \\
\text { Stable } \\
\end{array}$ & - \\
\hline $\begin{array}{c}\text { Information } \\
\text { Technologies }\end{array}$ & & - & - & - & - & - & - & - & - \\
\hline Tourism & & - & - & - & - & - & - & - & - \\
\hline $\begin{array}{l}\text { Production } \\
\text { Technology }\end{array}$ & & - & - & $\begin{array}{c}\text { Low spec. } \\
\text { Stable }\end{array}$ & - & - & - & - & - \\
\hline \multicolumn{10}{|c|}{$\begin{array}{l}\text { Source: The table is constructed based on the results presented in section } 2 \text { methodology implementation. Detailed results are presented in } \\
\text { Section 3. Abbreviation «Spec.» refers to the term «Specialization. Symbol «-» refers to the situation, when a cluster's critical mass is too } \\
\text { low, i.e. it is now identified in the region. The first line each box presents the evaluation result of region specialization in types of activities } \\
\text { performed by a cluster } i \text { in the region g. (see Table } 2 \text { for more details). The second line refers to the type of dynamic state of employment of } \\
\text { cluster } i \text { in region g. (see Table } 3 \text { for more details). }\end{array}$} \\
\hline
\end{tabular}

Table 15. Cross-matrix of the state of development of the clusters in Russian Regions for 2009-2016

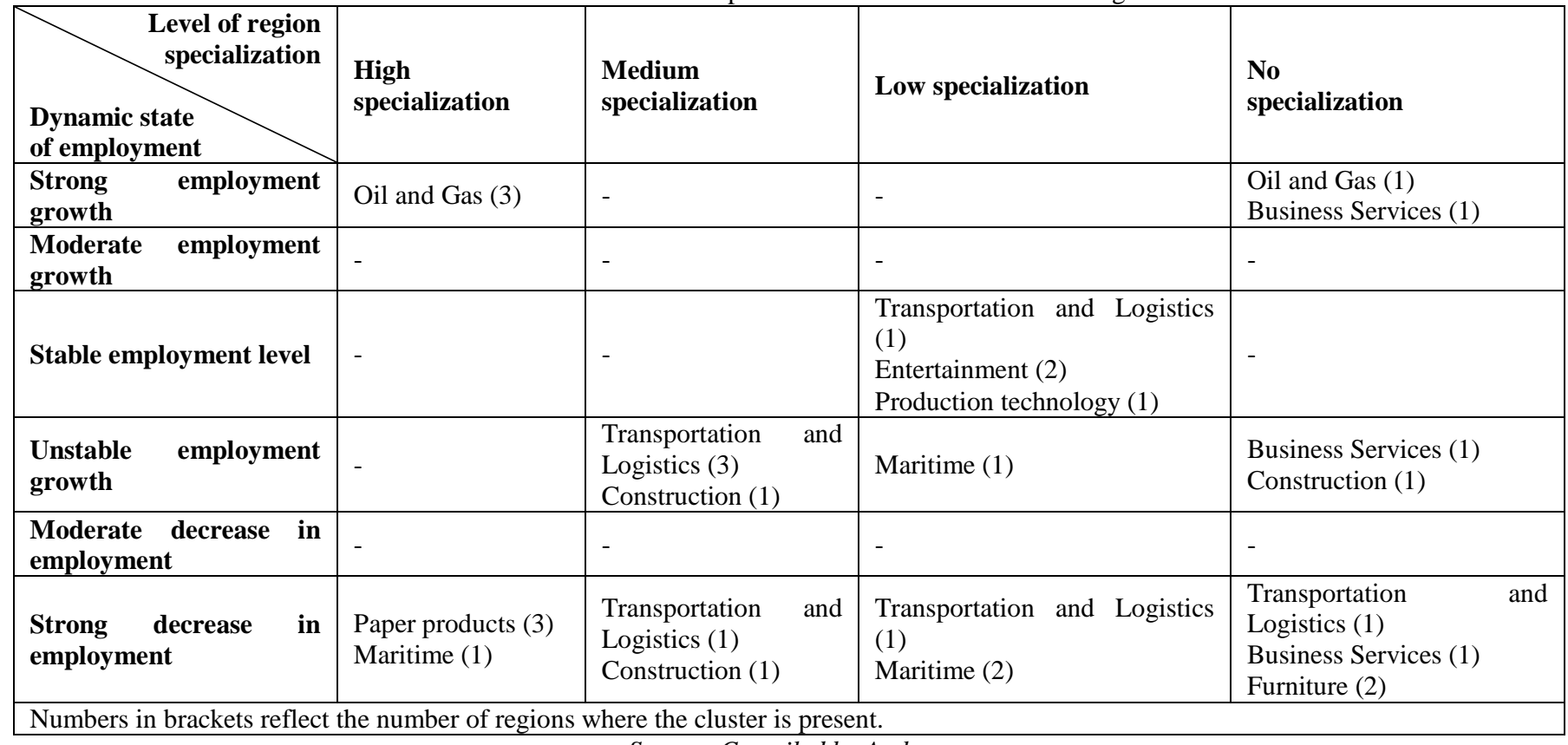




\section{ENTREPRENEURSHIP AND SUSTAINABILITY ISSUES}

ISSN 2345-0282 (online) http://jssidoi.org/jesi/

2020 Volume 8 Number 1 (September)

http://doi.org/10.9770/jesi.2020.8.1(10)

\section{Discussion and conclusion}

This research study provides several results, which contribute both to practical and theoretical fields.

First, we present the architecture of the database for automated identification of clusters in the Russian regions. This architecture can be used for creating any other database to calculate cluster localization parameters in any other country or region.

Secondly, we, in brief, present methodology for cluster identification and discuss how clusters can be identified from the perspective of the European Cluster Observatory. We complement this methodology through presenting two additional dimensions, which can be used for better interpretation and systematization of results. The dimension «Level of region specialization» depends on the average number of stars obtained by a certain cluster in a certain region. The dimension «Dynamic state of employment» represents the pattern of employment change during the analyzed period.

Thirdly, we present the main results for cluster identification using the example of the Russian Arctic regions. It is stated that most of the significant clusters are decreasing, while the only cluster which achieved steady growth in terms of localization parameters was «Oil and Gas». The obtained results allowed us to conclude that the cluster structure of the Russian Arctic regions is poor in the sense that there are few significant clusters and that most of them are weak and decreasing. This result can be used as a basis for elaborating regional economic policy to support regional diversification and specialization.

There are also several opportunities for further research. Firstly, the presented database can be modified in order to provide results, which are more valuable. Currently it calculates only four parameters, which reflect localization parameters and regional specialization. It can be expanded in order to calculate more metrics, which are based not only on employment data, but also on salary and sales data of the clusters. In addition, functions can be included to compose indexes based on several parameters. In addition, it could be interesting to tackle the technical issues connected with data input. At the moment, before data are input to the database, a big job has to be done, which is connected to acquiring and formatting data. If it were possible to connect the database directly to the State Statistical Service systems, the time spent waiting to receive a result would significantly decrease.

\section{Funding}

The reported study was funded by the Russian Foundation for Basic Research (research project No. 18-31020012).

\section{Author Contributions}

Conceptualization, A.S., T.K., M.A.B.; Methodology, T.K.; Validation, A.S. and T.K.; Formal Analysis, A.S.; Investigation, A.S. and T.K.; Data Curation, A.S.; Writing-Original Draft Preparation, A.S., T.K., M.A.B.; Writing-Review \& Editing, T.K., M.A.B.; Visualization, A.S.; Supervision, T.K.; Project Administration, T.K.; Funding Acquisition, T.K.

\section{Conflicts of Interest}

The authors declare no conflict of interest. 


\section{ENTREPRENEURSHIP AND SUSTAINABILITY ISSUES}

ISSN 2345-0282 (online) http://jssidoi.org/jesi/ 2020 Volume 8 Number 1 (September)

http://doi.org/10.9770/jesi.2020.8.1(10)

\section{References}

Akpinar, M., Can, Ö., \& Mermercioglu, M. (2017). Assessing the sources of competitiveness of the US states. Competitiveness Review: An International Business Journal, 27(2), 161-178. https://doi.org/10.1108/CR-02-2016-0014

Andreyeva, D. A., Irina, I. V. K., Dvas, G. V., Malinin, A. M., \& Nadezhina, O. S. (2018). Factors of effective regional development and labor market condition as indicator of state of the economy of the region. Proceedings of the 31st International Business Information Management Association Conference, 5507-5513.

Baltgailis, J. (2019). The issues of increasing the effectiveness of teaching comparative economics. Insights into Regional Development, 1(3), 190-199. https://doi.org/10.9770/ird.2019.1.3(1)

Berawi, M. A. (2017). Empowering Added Value in Highway Project: A Strategy to Improve the Feasibility. Highway Engineering, 67. https://doi.org/10.5772/intechopen.71778

Berawi, M. A., Susantono, B., Miraj, P., \& Nurmadinah, F. (2018). Prioritizing airport development plan to optimize financial feasibility. Aviation, 22(3), 115-128. https://doi.org/10.3846/aviation.2018.6589

Borisov, V. N., \& Pochukaeva, O. V. (2016). Relationships between development factors of the Arctic Zone of the Russian Federation. Studies on Russian Economic Development, 27(2), 159-165.

Bublienė, R., Vinogradova, I., Tvaronavičienè, M., Monni, S. (2019). Legal form determination for the development of clusters‘ activities. Insights into Regional Development, 1(3), 244-258. https://doi.org/10.9770/ird.2019.1.3(5)

Chun, S., Shulman, S., Sandoval, R., \& Hovy, E. (2010). Government 2.0: Making connections between citizens, data and government. Information Polity, 15(1,2), 1-9. https://doi.org/10.3233/IP-2010-0205

Crawley, A., \& Pickernell, D. (2012). An appraisal of the European cluster observatory. European Urban and Regional Studies, 19(2), 207211. https://doi.org/10.1177/0969776411427328

Degtereva, V. A., Zaborovskaia, O. V., \& Sharafanova, E. E. (2018). Methodology of targeted support for service sector enterprises in regional economic system. Proceedings of the 31st International Business Information Management Association Conference, 955-966.

Delgado, M., Porter, M. E., \& Stern, S. (2014). Clusters, convergence, and economic performance. Research Policy, 43(10), 1785-1799. https://doi.org/10.3386/w18250

Delgado, M., Porter, M. E., \& Stern, S. (2015). Defining clusters of related industries. Journal of Economic Geography, 16(1), 1-38. https://doi.org/10.1093/jeg/lbv017

Dvas, G., Lyukevich, I., \& Kulagina, N. (2018). Optimization of administration decentralization as a key mechanism for implimentation of regional politics. Proceedings of the 32nd International Business Information Management Association Conference, $3933-3949$.

Federal State Statistics Service. (2019). Central statistical database of Russia. Retrieved February 11, 2019, from http://www.gks.ru/dbscripts/cbsd/dbinet.cgi\#1

Gupta, M., Jacobi, R., Jamet, J.-F., \& Malik, L. (2006). The LA Motion Picture Industry Cluster. The Microeconomics of Competitiveness: Firms, Clusters and Economic Development, Harvard Business School.

Gutman, S., Kozlov, A., \& Teslya, A. (2018). Sustainable development of industrial enterprises in one-industry towns through harmonization of main stakeholders' interests: Case of Russian arctic zone. In Soliman \& K.S. (Eds.), Proceedings of the 31 st International Business Information Management Association Conference (pp. 3014-3023). International Business Information Management Association, IBIMA.

Guzman, J., \& Stern, S. (2015). Where is Silicon Valley? Science, 347(6222), 606-609. https://doi.org/10.1126/science.aaa0201

Höchtl, J., Parycek, P., \& Schöllhammer, R. (2016). Big data in the policy cycle: Policy decision making in the digital era. Journal of Organizational Computing and Electronic Commerce, 26(1-2), 147-169. https://doi.org/10.1080/10919392.2015.1125187

HSE. (2018). Joint economic and social data archive of Higher School of Economics. Retrieved February 11, 2019, from http://sophist.hse.ru/eng/ 


\section{ENTREPRENEURSHIP AND SUSTAINABILITY ISSUES}

ISSN 2345-0282 (online) http://jssidoi.org/jesi/ 2020 Volume 8 Number 1 (September)

http://doi.org/10.9770/jesi.2020.8.1(10)

Islankina, E., \& Thurner, T. W. (2018). Internationalization of cluster initiatives in Russia: empirical evidence. Entrepreneurship \& Regional Development, 1-24. https://doi.org/10.1080/08985626.2018.1457086

Ketels, C., \& Protsiv, S. (2014). European cluster panorama 2014. Center for Strategy and Competitiveness, Stockholm School of Economics, October.

Kichigin, O. E. (2017). Fossil Fuel Production Impact on Regional Eco-Economic Development. International Journal of Ecological Economics and StatisticsTM, 38(4), 12-22.

Komkov, N. I., Selin, V. S., Tsukerman, V. A., \& Goryachevskaya, E. S. (2017). Problems and perspectives of innovative development of the industrial system in Russian Arctic regions. Studies on Russian Economic Development, 28(1), 31-38.

Kopczewska, K. (2018). Cluster-based measures of regional concentration. Critical overview. Spatial Statistics, 27(September), 31-57. https://doi.org/10.1016/j.spasta.2018.07.008

Kopczewska, K., Churski, P., Ochojski, A., \& Polko, A. (2017). Measuring Regional Specialisation. In Measuring Regional Specialisation: A New Approach. https://doi.org/10.1007/978-3-319-51505-2

Korovkin, A. G. (2016). Macroeconomic assessment of the state of regional labor markets in the Asian part of the Russian Arctic. Studies on Russian Economic Development, 27(2), 166-179.

Kozlov, A. V, Gutman, S. S., Rytova, E. V, \& Zaychenko, I. M. (2017). The application of the fuzzy sets theory to valuing cumulative labor potential of the region. Soft Computing and Measurements (SCM), 2017 XX IEEE International Conference On, 621-623. IEEE.

Kutsenko, E., Islankina, E., \& Abashkin, V. (2017). The evolution of cluster initiatives in Russia: the impacts of policy, life-time, proximity and innovative environment. Foresight, 19(2), 87-120. https://doi.org/10.1108/FS-07-2016-0030

Leksin, V., \& Porfiryev, B. (2017). Socio-Economic Priorities for the Sustainable Development of Russian Arctic Macro-Region. Economy of Region, 1(4), 985-1004. https://doi.org/10.17059/2017-4-2

Lindqvist, G. (2009). Disentangling clusters agglomeration and proximity effects. Elanders, Vällingby.

Looijen, A., \& Heijman, W. (2013). European agricultural clusters: how can European agricultural clusters be measured and identified? Ekonomika Poljoprivrede, 60(2), 337.

MATICIUC, M. (2015). The complex relation between clusters and innovation in European Union. Ecoforum Journal, 4(2).

MinComSvyaz. (2019). United interdepartmental information - statistical service. Retrieved February 11, 2019, from https://fedstat.ru/

Morrissey, K. (2016). A location quotient approach to producing regional production multipliers for the Irish economy. Papers in Regional Science, 95(3), 491-506. https://doi.org/10.1111/pirs.12143

Peiró-Signes, A., Segarra-Oña, M. del V., Miret-Pastor, L., \& Verma, R. (2015). The Effect of Tourism Clusters on U.S. Hotel Performance. Cornell Hospitality Quarterly, 56(2), 155-167. https://doi.org/10.1177/1938965514557354

Petrenko, Y., Vechkinzova, E., Antonov, V. (2019). Transition from the industrial clusters to the smart specialization of the regions in Kazakhstan. Insights into Regional Development, 1(2), 118-128. https://doi.org/10.9770/ird.2019.1.2(3)

Porter, Michael E., Ramirez-Vallejo, J., Puri, A., Demirsoy, I., Woods, L., Zhou, M., \& Rattanaruengyot, T. (2011). The Minnesota medical devices cluster. Microeconomics of Competitiveness, 1-36.

Porter, Michael E. (1998). Clusters and competition: New agendas for companies, governments, and institutions. In M.E. Porter (Ed.), Governments and Institutions, in: Ibid., On Competition (pp. 197-299). Boston, MA: Harward Business School Press.

Prodani, R., Bushati, J., Andersons, A. (2019). An assessment of impact of information and communication technology in enterprizes of Korça region. Insights into Regional Development, 1(4), 333-342. https://doi.org/10.9770/ird.2019.1.4(4)

Razminienè, K., Tvaronavičienė, M. (2018). Detecting the linkages between clusters and circular economy, Terra Economicus, 16(4), 5065. https://doi.org/10.23683/2073-6606-2018-16-4-50-65 


\section{ENTREPRENEURSHIP AND SUSTAINABILITY ISSUES}

ISSN 2345-0282 (online) http://jssidoi.org/jesi/ 2020 Volume 8 Number 1 (September)

http://doi.org/10.9770/jesi.2020.8.1(10)

Rodionova, E. A., Trifonova, N. V, Epstein, M. Z., \& Shvetsova, O. A. (2017). Multicriterial approach to estimation of economic efficiency based on regional innovative cluster. Soft Computing and Measurements (SCM), 2017 XX IEEE International Conference On, 743-745. IEEE.

Romashkina, G. F., Didenko, N. I., \& Skripnuk, D. F. (2017). Socioeconomic modernization of Russia and its Arctic regions. Studies on Russian Economic Development, 28(1), 22-30.

Rytova, E. V., Gutman, S. S., \& Zaychenko, I. M. (2017). Classification of the Russian Arctic zone territories according to the level of small business development. In K. S. Soliman (Ed.), Proceedings of the 30th International Business Information Management Association Conference, IBIMA 2017 - Vision 2020: Sustainable Economic development, Innovation Management, and Global Growth (pp. 32183223). International Business Information Management Association, IBIMA.

Rytova, E., \& Gutman, S. (2019). Assessment of regional development strategy in the context of economy digitization on the basis of fuzzy set method. IOP Conference Series: Materials Science and Engineering, 497(1). https://doi.org/10.1088/1757-899X/497/1/012060

Schepinin, V., Skhvediani, A., \& Kudryavtseva, T. (2018). An empirical study of the production technology cluster and regional economic growth in Russia. In M. P. C. Amorim, C. Costa, \& M. Au-Yong-Oliveira (Eds.), Proceedings of the European Conference on Innovation and Entrepreneurship, ECIE (pp. 732-740). Academic Conferences and Publishing International Limited. https://doi.org/10.1051/shsconf/20184400050

Sellar, C., Emilova, M., Petkova-Tancheva, C. D., \& McNeil, K. (2011). Cluster policies in Bulgaria: European integration, postsocialist dynamics and local level initiatives. International Journal of Urban and Regional Research, 35(2), 358-378. https://doi.org/10.1111/j.1468$\underline{2427.2010 .00959 . x}$

Tatarkin, A. I., Loginov, V. G., \& Zakharchuk, E. A. (2017). Socioeconomic problems in development of the Russian Arctic zone. Herald of the Russian Academy of Sciences, 87(1), 12-21.

Thill, J.-C. (2019). Spatial multicriteria decision making and analysis: a geographic information sciences approach. Routledge.

Tvaronavičienè, M. (2017). Clusters, innovations and energy efficiency: if relantionship could be traced. Marketing and Management of Innovations, 2, 382-391. http://doi.org/10.21272/mmi.2017.2-35

Tvaronavičienė, M., Razminienė K. (2017). Towards competitive regional development through clusters: approaches to their performance evaluation, Journal of Competitiveness, 9(4), 133-147, https://doi.org/10.7441/joc.2017.04.09

Velasquez, M., \& Hester, P. T. (2013). An analysis of multi-criteria decision making methods. International Journal of Operations Research, 10(2), 56-66. 


\section{ENTREPRENEURSHIP AND SUSTAINABILITY ISSUES}

ISSN 2345-0282 (online) http://jssidoi.org/jesi/ 2020 Volume 8 Number 1 (September)

Tatiana KUDRYAVTSEVA

http://doi.org/10.9770/jesi.2020.8.1(10)

PhD, professor at Graduate School of Industrial Economics of Peter the Great St. Petersburg Polytechnic University. T. Kudryavtseva conducts the following courses: financial management, economic analysis, financial analysis. Her main fields of research are regional development, cluster-based industrial policy and evaluation of economic efficiency of industrial policy.

ORCID ID: orcid.org/0000-0003-1403-3447

\section{Angi SKHVEDIANI}

PhD student, assistant at Graduate School of Industrial Economics of Peter the Great St. Petersburg Polytechnic University. A. Skhvediani specializes in regional development studies. He conducts course on applied econometrics.

ORCID ID: orcid.org/0000-0001-7171-7357

\section{Mohammed Ali BERAWI}

$\mathrm{PhD}$, associate professor in the department of civil engineering, faculty of engineering, Universitas Indonesia. He has extensive research experience in value engineering/value management and innovation in the context of infrastructure, construction, and manufacturing industries.

ORCID ID: orcid.org/0000-0002-1580-6686

Make your research more visible, join the Twitter account of ENTREPRENEURSHIP AND SUSTAINABILITY ISSUES: @Entrepr69728810

Copyright (C) 2020 by author(s) and VsI Entrepreneurship and Sustainability Center

This work is licensed under the Creative Commons Attribution International License (CC BY).

http://creativecommons.org/licenses/by/4.0/

(c) (i) Open Access 